\title{
Albert Terelak
}

Uniwersytet Szczeciński

\section{Szczecin w świadomości jego mieszkańców. Perspektywa zakorzenienia*}

STRESZCZENIE W artykule zaprezentowano założenia metodologiczne oraz wyniki badań przeprowadzonych wśród szczecinian mieszczących się w mobilnych kategoriach wieku produkcyjnego (25-44 lata), dotyczących postrzegania stolicy Zachodniopomorskiego przez jej mieszkańców. Ustalenia z analizy wyników badań odnoszą się w poniższym tekście do problematyki: 1) ogólnego stosunku do Szczecina jako miejsca życia, pozwalającej określić, na ile jest on traktowany jako „własne miejsce na ziemi”; 2) elementów zbiorowej autopercepcji szczecinian wyrażającej się w ocenach zestawu stwierdzeń opisujących społeczeństwo miasta. Istotny poznawczo kontekst przeprowadzonej analizy tworzy zestawienie sposobów postrzegania miasta ze zmiennymi zakorzenienia (urodzenie w Szczecinie lub osiedlenie się w nim, rodzinne korzenie szczecińskie lub ich brak).

\author{
SŁOWA KLUCZOWE \\ KAPITAŁ LUDZKI, \\ PERCEPCJA MIASTA, \\ TOŻSAMOŚĆ SPOŁECZNA, \\ SPOŁECZNE \\ ZAKORZENIENIE, \\ WIĘŹ LOKALNA
}

\footnotetext{
· Artykuł jest szkicem obrazu specyfiki postrzegania stolicy Pomorza Zachodniego przez jej mieszkańców mieszczących się w dynamicznych kategoriach wieku produkcyjnego (25-44 lata). Wprowadzenie dla podjętych w tekście rozważań stanowi artykuł Alberta Terelaka i Sebastiana Kołodziejczaka Szczecin jako przestrzeń życia i rozwoju w świadomości jego aktywnych zawodowo mieszkańców w kontekście rekompozycji rynków pracy Pomorza Zachodniego, zamieszczony w niniejszym numerze „Opuscula Sociologica” (s. 51-62), zawierający szkic obrazu sytuacji na regionalnym rynku pracy w perspektywie lat 2005-2014. Z kolei kontynuacją rozważań nad obrazem Szczecina w świadomości jego mieszkańców jest artykuł Sebastiana Kołodziejczaka Warunki rozwojowe Szczecina w świadomości jego mieszkańców. Perspektywa zakorzenienia, zamieszczony również w tym numerze (s. 91-108).
} 
W badaniach zrealizowanych w 2015 roku na próbie $n=1003$ szczecinian mieszczących się w dynamicznych kategoriach wieku produkcyjnego (25-44 lata) podjęto problematykę postrzegania Szczecina jako miejsca życia i realizacji celów życiowych, stosując technikę skalowania metodą Likerta i selekcjonując piętnaście stwierdzeń na temat Szczecina grupujących się w czterech podstawowych wymiarach:

1. Stosunek do Szczecina w ujęciu ogólnym, akcentującym głównie afektywny komponent postawy.

Stwierdzenia:

- Kocham Szczecin;

- Szczecin z roku na rok staje się piękniejszy;

- Szczecinianie mają więcej powodów do dumy ze swojego miasta niż powodów do wstydu;

- Na przestrzeni lat Szczecin staje się coraz bardziej prowincjonalnym miastem;

- Wolałabym/wolałbym mieszkać w innym niż Szczecin miejscu Polski lub poza Polską.

2. Stosunek do mieszkańców Szczecina.

Stwierdzenia:

- Mieszkaniec Szczecina to brzmi dumnie;

- Gdy myślę ogólnie mieszkańcach Szczecina, mogę o nich powiedzieć więcej dobrego niż złego;

- Szczecinianom brakuje wzajemnej więzi.

3.Stosunek do władz Szczecina.

Stwierdzenia:

- Szczecin ma dobre władze;

- Władza w Szczecinie słabo radzi sobie z tworzeniem warunków sprzyjających rozwojowi;

- To, co jest dobre w Szczecinie, częściej jest marnotrawione niż wykorzystywane dla jego świetności.

4. Ocena możliwości osobistego rozwoju w Szczecinie.

Stwierdzenia:

- W Szczecinie panują dogodne warunki do osiągnięcia sukcesu przez ludzi z inicjatywą;

- Jeśli ktoś ma wysokie ambicje zawodowe, to większe szanse na ich spełnienie dają inne niż Szczecin duże miasta Polski;

- Gdybym żyła/żył w innym dużym mieście Polski, miałabym/miałbym większe możliwości realizacji celów;

- Inne duże miasta Polski rozwijają się szybciej niż Szczecin.

Analizowany zestaw stwierdzeń odwołuje się do zasadniczych elementów świadomościowej konstrukcji obrazu miasta, pozwalających charakteryzować stosunek do niego wyrażany przez tych mieszkańców, którzy tu właśnie realizują - z większymi lub mniejszymi sukcesami - swoje cele życiowe i ambicje zawodowe. Przestrzeń własności zmiennych niezależnych ważnych dla charakterystyki przekonań na temat Szczecina uwzględnia oprócz płci, wieku i poziomu wykształcenia fakt, że poddana badaniu zbiorowość składa się z osób tu urodzonych oraz osiedlonych, a nadto w obydwu tych kategoriach istotne składowe stanowią osoby mające szczecińskie korzenie w rodzinach (w pokoleniu rodziców bądź głębsze) oraz takie, których rodziny nie są związane ze Szczecinem. Przyjęto

${ }^{1}$ Wszystkie poddane analizie stwierdzenia osiągnęły, w analizie selekcyjnej postawy, poziom współczynnika korelacji C-Pearsona wyższy niż 0,9 (por. Oppenheim, 2004, s. 230). 
bowiem, że kategoria osiedlonych w Szczecinie oraz kategoria osób niemających szczecińskich korzeni rodzinnych są na tyle liczne w strukturze badanej zbiorowości, że warto sprawdzić ich znaczenie dla postrzegania miasta, w którym żyją. Zatem na etapie konceptualizacji problematyki badania postawiono problem znaczenia powyższych zmiennych (niezależnych) dla przekonań na temat stolicy Pomorza Zachodniego. Charakterystyka próby ze względu na miejsce urodzenia została przedstawiona w tabeli 1.

Tabela 1

Geneza szczecińskiej tożsamości szczecinian w wieku 25-44 lata

\begin{tabular}{|l|c|c|}
\hline \multicolumn{1}{|c|}{ Wyszczególnienie } & Liczebność & $\%$ \\
\hline Urodzeni w Szczecinie & 592 & 59,0 \\
\hline Osiedleni w Szczecinie & 397 & 39,6 \\
\hline Brak danych & 14 & 1,4 \\
\hline Ogółem & 1003 & 100,0 \\
\hline
\end{tabular}

Źródło: badania własne.

Jak wynika z uzyskanych danych, niemal 60\% uczestników badania to osoby urodzone w Szczecinie. Należy zwrócić uwagę na to, że co trzeci mieszkaniec Szczecina w wieku 25-44 lat nie ma rodzinnych korzeni w tym mieście, co zobrazowano w tabeli 2.

Tabela 2

Szczecińskie korzenie w rodzinach

\begin{tabular}{|l|c|c|}
\hline \multicolumn{1}{|c|}{ Wyszczególnienie } & Liczebność & $\%$ \\
\hline Brak szczecińskich korzeni w rodzinie & 307 & 30,6 \\
\hline Szczecińskie korzenie w rodzinie & 675 & 67,3 \\
\hline Nieokreślona geneza szczecińskiej tożsamości & 21 & 2,1 \\
\hline Ogółem & 1003 & 100,0 \\
\hline
\end{tabular}

Źródło: badania własne.

Bardziej precyzyjne wejrzenie w zagadnienie korzeni rodzinnych uczestników badania pozwala dostrzec ponadczterdziestoprocentowy udział osób, których rodzinne związki ze Szczecinem sięgają dwóch pokoleń (rodzice i dziadkowie). Stanowią one trzecie pokolenie szczecinian. Natomiast udział osiemnastoprocentowy mają ci, których związki ze Szczecinem sięgają tylko jednego pokolenia - rodziców. Ci mieszkańcy stolicy województwa zachodniopomorskiego są przedstawicielami drugiego pokolenia szczecinian. Innymi słowy, są to urodzone w Szczecinie dzieci osiedleńców.

Interesującym aspektem postaw przyjmowanych przez mieszkańców wobec Szczecina jest geneza ich tożsamości terytorialnej. Przeciętny wiek osób osiedlonych wynosi 29,3 lat, a średnia liczba lat, które upłynęły od przybycia do Szczecina, wynosi 14,3. Osoby, które napłynęły do Szczecina przed ukończeniem piętnastego roku życia, to 15,9\% kategorii osiedlonych. W wieku od 15 do 25 lat osiedliło się 59,4\%, natomiast w późniejszym okresie życia - 19,4\%. To oznacza, że istotna kategoria osób przybywa do Szczecina w latach młodzieńczych, kiedy podstawowe zręby ich indywidualnej i społecznej tożsamości jeszcze są budowane. Jedynie niewiele mniej niż co piąty osiedlający się w Szczecinie uczynił to po ukończeniu 25 lat. Należy podkreślić, że większość osiedleńców (62,5\%) pochodzi 
z Pomorza Zachodniego, przy czym jeśli pominąć przybywających z Koszalina - drugiego pod względem wielkości miasta regionu - to 58,2\% osiedlających się w Szczecinie stanowią przybysze z małych miejscowości. Przeprowadzka z małej miejscowości do dużego miasta - stolicy regionu oznacza awans społeczny. Dodatkowo należy podkreślić, że $77,1 \%$ osiedleńców to osoby niemające żadnych powiązań pokoleniowych ze Szczecinem.

Tabela 3

Szczecińska tożsamość szczecinian w wieku 25-44 lata

\begin{tabular}{|l|r|r|}
\hline \multicolumn{1}{|c|}{ Wyszczególnienie } & Liczebność & $\%$ \\
\hline Urodzeni w Szczecinie, nieokreślone szczecińskie korzenie w rodzinie & 5 & 0,5 \\
\hline Urodzeni w Szczecinie, bez szczecińskich korzeni w rodzinie & 1 & 0,1 \\
\hline Urodzeni w Szczecinie, szczecińskie korzenie w pokoleniu rodziców & 181 & 18,1 \\
\hline Urodzeni w Szczecinie, szczecińskie korzenie w pokoleniu rodziców i w pokoleniu dziadków & 405 & 40,4 \\
\hline Osiedleni w Szczecinie, nieokreślone szczecińskie korzenie w rodzinie & 2 & 0,2 \\
\hline Osiedleni w Szczecinie, bez szczecińskich korzeni w rodzinie & 306 & 30,5 \\
\hline Osiedleni w Szczecinie, szczecińskie korzenie w pokoleniu rodziców & 62 & 6,2 \\
\hline Osiedleni w Szczecinie, szczecińskie korzenie w pokoleniu rodziców i w pokoleniu dziadków & 21 & 2,1 \\
\hline Osiedleni w Szczecinie, szczecińskie korzenie w pokoleniu dziadków & 6 & 0,6 \\
\hline Nieokreślona geneza szczecińskiej tożsamości & 14 & 1,4 \\
\hline Ogółem & 1003 & 100,0 \\
\hline
\end{tabular}

Źródło: badania własne.

Poddane analizie zestawy stwierdzeń na temat Szczecina (ogólnie), jego władz, mieszkańców oraz poziomu rozwoju i warunków dla realizacji osobistych celów, o ustosunkowanie do których poproszono w kwestionariuszu uczestników badania, pozwalają uchwycić zasadnicze elementy obrazu miasta w świadomości tej kategorii jego mieszkańców, która jest w bodaj największym stopniu uwikłana zarówno we wszystkie aspekty kondycji lokalnego rynku pracy, jak i w jej uwarunkowania. Stąd opinie wyrażone w ocenach treści poszczególnych stwierdzeń egzemplifikują z jednej strony potencjał wartości, jaką jest miejsce zamieszkania dla ludzi aktywnie uczestniczących w lokalnym rozwoju, a z drugiej strony potencjał rezerwuaru społecznej partycypacji wynikającej z poziomu identyfikacji z tym miejscem.

Rozkłady odpowiedzi na pytanie o poziom zgody (lub jej braku) z tym, co głoszą zdania tworzące pierwszy kompleks stwierdzeń odwołujących się przede wszystkim do afektywnego komponentu postawy wobec Szczecina, zostały przedstawione na wykresie 1. Ze względu na to, że treść pierwszych trzech kategorii jest logicznie przeciwna treści dwóch ostatnich, odwrócono zestawienie kategorii odpowiedzi - dla zachowania przejrzystości podziału: negatywny stosunek, pozytywny stosunek. 
Stosunek do Szczecina w ujęciu ogólnym - zestawienie rozkładów opinii (\%)

Kocham Szczecin

Zdecydowanie nie do zdecydowanie tak

Raczej nie do raczej tak

Trudno powiedzieć

Brak danych

Negatywny stosunek Pozytywny stosunek

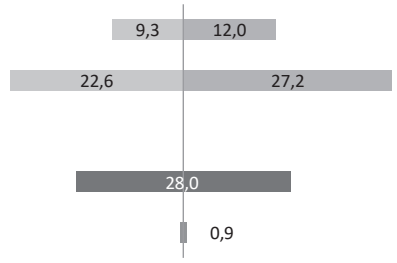

Szczecin z roku na rok staje się piękniejszy

Zdecydowanie nie do zdecydowanie tak

Raczej nie do raczej tak

Trudno powiedzieć

Brak danych

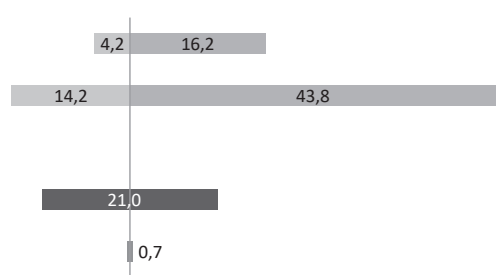

Szczecinianie mają więcej powodów do dumy ze swego miasta niż powodów do wstydu

Zdecydowanie nie do zdecydowanie tak

Raczej nie do raczej tak

Trudno powiedzieć

Brak danych

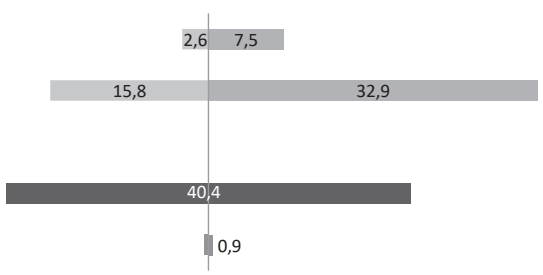

Na przestrzeni lat Szczecin staje się coraz bardziej prowincjonalnym miastem

Zdecydowanie tak do zdecydowanie nie

Raczej tak do raczej nie

Trudno powiedzieć

Brak danych

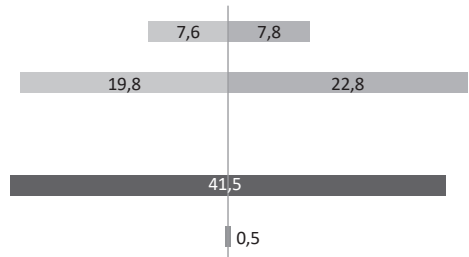

Wolałabym/wolałbym mieszkać w innym niż Szczecin miejscu Polski lub poza Polską

Zdecydowanie tak do zdecydowanie nie

Raczej tak do raczej nie

Trudno powiedzieć

Brak danych

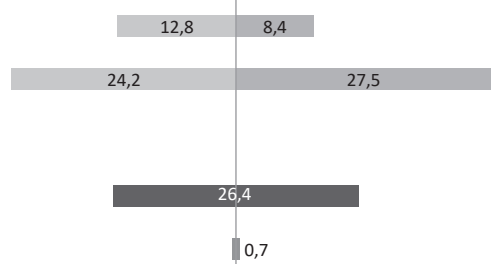

$n=1003=100 \%$.

Źródło: badania własne. 
Zestawienie opinii uczestników badania na temat kompleksu elementów uosabiających emocjonalne przywiązanie do miejsca zamieszkania i równocześnie należących do samej podstawy lokalnej tożsamości mieszkańców pozwala unaocznić kilka wartych głębszego namysłu prawidłowości oraz poczynić wyjściowe ustalenia na temat postaw istotnej części szczecinian wobec ich miasta. Po pierwsze, należy podkreślić, że przeważa ogólne pozytywne nastawienie do Szczecina. Udział opinii pozytywnych w aspektach miłości do Szczecina, uroku miasta, powodów mieszkańców do dumy wobec powodów do wstydu wyraźnie przeważa nad udziałem opinii negatywnych. Natomiast pod względem obecnego w dyskursie publicznym procesu peryferyzacji Szczecina oraz chęci zamieszkiwania gdzie indziej opinie się równoważą; różnica między udziałem opinii negatywnych i pozytywnych jest nieistotna statystycznie. Po drugie, wielkość wskazanych przewag raczej prowokuje do refleksji nad obliczem Szczecina jako miejsca, z którym ludzie wiążą swoje uczucia. Nie sposób bowiem nie zadać w tym momencie pytania o to, dlaczego przewaga udziału uczuć pozytywnych nad negatywnymi nie jest większa. Postawienie takiego pytania jest o tyle uzasadnione, że dominującą część respondentów stanowią osoby niedeklarujące pozytywnego stosunku do Szczecina. Jeśli - dla przykładu - 39,2\% uczestników badania deklaruje miłość do Szczecina, to 31,9\% wyrażających przeciwną opinię i 28,0\% niezdecydowanych ujawnia niemal sześćdziesięcioprocentową większość osób niedeklarujących miłości do Szczecina. Co prawda, w przypadku dwóch stwierdzeń przewaga opinii pozytywnych nad negatywnymi jest duża (stwierdzenie na temat rosnącego uroku Szczecina - 60,0\% opinii pozytywnych do 18,4\% opinii negatywnych, stwierdzenie na temat powodów do dumy lub wstydu dostarczanych szczecinianom przez ich miasto - 40,4\% opinii pozytywnych do 18,4\% opinii negatywnych), przy czym udział postaw niezdecydowanych wobec drugiego stwierdzenia $(40,4 \%)$ jest niemal dwukrotnie wyższy niż w odniesieniu do pierwszego (21,0\%). Oznacza to, że również stwierdzenie: Szczecinianie mają więcej powodów do dumy ze swego miasta niż powodów do wstydu, odsłania nie całkiem pozytywny obraz miasta w tym względzie. Po trzecie, chociaż ogólnie pozytywny aspekt stosunku do miasta lekko dominuje nad aspektem negatywnym, jednak w zakresie ostatniego z analizowanych elementów tworzących emocjonalne przywiązanie do miejsca zamieszkania, wyrażonego stwierdzeniem: Wolałabym/wolałbym mieszkać w innym niż Szczecin miejscu Polski lub poza Polską, relacja udziału opinii wyrażających pozytywny stosunek do miasta do tych, które wyrażają stosunek negatywny, rodzi jeszcze dalej posunięte wątpliwości dotyczące wizerunku Szczecina jako miejsca życia i realizacji celów życiowych. O ile bowiem niemal 40\% szczecinian w wieku 25-44 lata kocha swoje miasto, 60\% uważa, że z każdym rokiem staje się ono piękniejsze, 40,4\% skłania się ku przekonaniu, że Szczecin daje więcej powodów do dumy niż do wstydu, o tyle w przypadku stwierdzenia głoszącego: Na przestrzeni lat Szczecin staje się coraz bardziej prowincjonalnym miastem, 30,6\% przeciwstawia się tej opinii, natomiast 68,9\% akceptuje pogląd o peryferyjnym charakterze miasta ich zamieszkania (27,4\%) albo nie ma w tym względzie wyrobionej opinii $(41,5 \%)$.

Konstatując powyższe uwagi, należy stwierdzić, że 35,9\% uczestników badania wyrażających chęć życia w Szczecinie do ponad 63\% deklarujących niechęć lub niezdecydowanie w tak fundamentalnym aspekcie wizerunku miasta tworzy dysproporcję, która skłania do refleksji nad przyszłością stolicy regionu. Zdecydowanie warto zastanowić się i rozważyć co najmniej kilka kwestii mających substancjalny związek z jakością oraz trwałością społecznego, gospodarczego i kulturowego oblicza miasta. Pierwszym zasadniczym problemem jest ten aspekt kondycji lokalnego rynku pracy, który wiąże się z cechami 
charakteryzującego go kapitału ludzkiego. W szczególności chodzi o udział osób legitymujących się wykształceniem wyższym oraz osób w wieku 25-29 lat, to znaczy kategorii najbardziej podatnych na oddziaływanie „sita selektywności migracji”2, czyli podlegających najsilniejszemu, przyciągającemu oddziaływaniu innych ośrodków zarówno w kraju, jak i za granicą. Wśród 63\% osób, które nie ujawniają takiego związania ze Szczecinem, by twierdzić, że wolałyby żyć w tym mieście niż gdzie indziej, udział osób z wyższym wykształceniem wynosi $52,3 \%$, natomiast $26,5 \%$ to osoby w wieku $25-29$ lat. Pozostali nie dysponują co prawda selektywnymi migracyjnie atutami na pozaszczecińskich rynkach pracy, co zmniejsza nieco ryzyko ich odpływu, ale nie sposób oprzeć się wrażeniu, że ten fakt nie stanowi szczególnie dużej szansy dla wzmocnienia kondycji lokalnego rynku pracy ani nie może być traktowany jako mocna strona Szczecina jako (chociażby) miejsca do inwestowania i wzrostu jakości życia mieszkańców. W kategorii osób niedeklarujących chęci mieszkania w Szczecinie dodatkowego wzmocnienia poczynionych ustaleń dostarcza udział osób zajmujących w strukturze swoich zakładów pracy kierownicze lub dyrektorskie stanowiska oraz osób będących właścicielami firm - wynosi on 25,9\%.

Drugim problemem domagającym się wyartykułowania jest stan integracji zbiorowości szczecinian oraz więzi lokalnej, które poprzez codzienne zachowania i działania, a także formułowane opinie wyrażające poczucie przynależności oraz społecznych i gospodarczych związków z innymi mieszkańcami i środowiskami społecznymi stanowią społeczno-kulturową osnowę progresywnej tożsamości lokalnej ludzi rzeczywiście partycypujących w rozwoju miasta bądź wręcz przejawiających gotowość do mobilizacji społecznej. Chodzi tu o powszechność tych postaw, które nie ograniczają się do oczekiwania na zmianę, do ekspresji niezadowolenia i tęsknoty za aktywnością władz, organizacji czy innych podmiotów życia społecznego miasta oraz do biernego trwania w zindywidualizowanej zbiorowości, lecz (z samej myśli o przynależności, z przeświadczenia o wspólnotowości) generują aktywizm i motywują najlepszych nie tylko do pozostania, lecz także do takiego podejmowania wyzwań rozwojowych, które Florian Znaniecki określił mianem „przodownictwa”3. Chodzi również o obecność w społecznym dyskursie na temat Szczecina narracji pozwalającej dostrzec w mieście „swoje miejsce na ziemi” - wywołującej poczucie związku z miastem i jego mieszkańcami, przekonanie o jego pozytywnie pojmowanej wyjątkowości w Polsce (ze względu na historię, walory urbanistyczne, architektoniczne, styl i jakość życia, stosunek do gości i siebie nawzajem itp.), czyli dającej pożywkę dla rozwoju, opartej na identyfikacji z miejscem zamieszkania tożsamości lokalnej szczecinian.

Jeżeli zatem specyfikę stosunku do Szczecina jego młodych, aktywnych zawodowo mieszkańców tworzy nieznaczna przewaga opinii pozytywnych nad negatywnymi, duży udział postaw niezdecydowanych oraz - nade wszystko - fakt, że około 63\% z nich nie

\footnotetext{
${ }^{2}$ Na podstawie wyników badań zagranicznych emigracji zarobkowych mieszkańców województwa zachodniopomorskiego należy stwierdzić, że największą selektywnością migracji cechuje się kategoria wyższego wykształcenia. Współczynnik selektywności migracji wynosi tu 1,84, co oznacza, że udział tej kategorii wykształcenia w strumieniu migracyjnym jest o 184\% większy niż w zbiorowości, z której migranci odpływają. Na drugim miejscu pod względem wielkości współczynnika selektywności migracji jest kategoria wieku 25-29 lat. Współczynnik selektywności migracji wynosi 1,2, czyli udział tej kategorii wieku jest o 120\% większy w strumieniu migracyjnym niż w zbiorowości, z której jej przedstawiciele odpływają (por. Terelak, Kołodziejczak, 2012c, s. 64-65).

${ }^{3}$ Koncepcja „przodowników społecznych” Floriana Znanieckiego, definiowanych jako osoby zdolne do pociągnięcia za sobą innych na drodze rozwoju grupy, a nadto - przynajmniej w początkowej fazie działalności - często niemające formalnego umocowania w strukturach grupy, ale oddziałujące na innych (na zasadzie dobrego przykładu oraz wewnętrznego optymizmu i zarażającej do działania wiary w sukces), ma jakże aktualne zastosowanie dla oglądu prorozwojowego (dla miasta) znaczenia więzi lokalnej jego mieszkańców (por. Znaniecki, 1990; Znaniecki, 1984, s. 96-98).
} 
deklaruje chęci mieszkania w tym mieście, to kwestia więzi i pozytywnej tożsamości lokalnej odznacza się wyraźnie znamionami deficytu.

Problem słabej więzi oraz specyficznej tożsamości lokalnej w Szczecinie ma swój wyraz również w ustaleniach innych badaczy. Dość wspomnieć znane badania Bohdana Jałowieckiego i Marka S. Szczepańskiego (2002), w których wykazują niską jakość kapitału społecznego stolicy Pomorza Zachodniego, pozostającą w powiązaniu z ograniczonymi więziami społecznymi mieszkańców. Wśród najświeższych opracowań warte uwagi są ustalenia Pawła Kubickiego (2016), w których na jeden z pierwszych planów wybija się fatalizm szczecinian w narracji na temat ich miasta. Autor twierdzi, że społeczeństwo Szczecina nigdy nie poradziło sobie z „mitem migranta w niechcianym mieście”, nigdy nie zakończyło „rytuału przejścia”, a tym samym nigdy nie wytworzyło tzw. mitu założycielskiego miasta swoich obywateli. Podkreśla on, że z tego właśnie względu mieszkańcom Szczecina brakuje emocjonalnych więzi z miastem (s. 316-331). Z kolei Maciej Kowalewski (2011) pisze na temat szczecińskich wydarzeń Grudnia '70 jako jedynych w powojennej historii Szczecina, które utrwaliły się we wspomnieniach mieszkańców, przy czym wydarzenia te nie stały się treścią „mitu założycielskiego”, a tym samym kanwą budowy poczucia wspólnotowości obywateli (s. 343-364).

Trzecim zagadnieniem do refleksji, powiązanym co prawda z omówioną powyżej kwestią więzi lokalnej, niemniej stanowiącym również samodzielną - konieczną do uwzględnienia w analizie - perspektywę, jest wpływ zakorzenienia w Szczecinie na postrzeganie miasta przez jego mieszkańców. Sformułowane powyżej tezy na temat tożsamości lokalnej młodych, aktywnych zawodowo szczecinian oraz ich ograniczonego przywiązania do miejsca zamieszkania nie mogą sprowadzać się jedynie do aspektu deskryptywnego - wyrażającego się pod postacią samych tylko mentalnych obrazów miasta i mieszkańców - ale domagają się uwzględnienia genetycznych z nim związków. Dopiero wtedy ustalenia na temat obrazu stolicy Pomorza Zachodniego, obecnego w świadomości żyjących tu ludzi, ujawnią pełnię znaczenia, gdy ich treść zostanie spenetrowana w poszukiwaniu zakresu oddziaływania zakorzenienia w Szczecinie. Inaczej rzecz ujmując, całe znaczenie wspomnianych ustaleń ujawni się w obliczu rozwiązania następującego problemu: czy bycie szczecinianinem z urodzenia lub z osiedlenia, i dalej - czy szczecińskie korzenie w rodzinie lub ich brak (w pokoleniu rodziców i/lub dziadków) pozwala w jakiejś mierze wyjaśniać zróżnicowanie sposobu postrzegania Szczecina. Można bowiem przyjąć założenie, że tym bardziej niepokojące znaczenie mają uwagi o słabej więzi lokalnej szczecinian, w im mniejszym stopniu zróżnicowanie opinii na temat poszczególnych elementów oblicza miasta wyjaśnia geneza szczecińskiej tożsamości uczestników badania (szczecinianie z urodzenia czy z osiedlenia) oraz ich pokoleniowe związki (lub ich brak) z miastem. Jeżeli zatem genetyczne zakorzenienie w mieście nie przekładałoby się na stosunek do niego jako miejsca życia oraz osiągania osobistych celów i uczestnictwa w tworzeniu pozytywnej narracji „szczecińskości” i wreszcie realizacji społecznych więzi, to ani długie (jedno-, dwu- czy trzypokoleniowe) trwanie tożsamości mieszkańców Szczecina, ani awans społeczny, jakim jest napływ z niezliczonych małych miejscowości w głębi regionu, nie dawałyby pożywki dla mentalnych związków z miastem.

Jeśli zatem wziąć pod uwagę zależność między rozkładem opinii na temat pierwszego ze stwierdzeń odwołujących się do ogólnie pojmowanego obrazu miejsca zamieszkania szczecinian biorących udział w badaniu a zmienną geneza szczecińskiej tożsamości oraz zmienną szczecińskie korzenie rodzinne, to na uwagę zasługuje kilka interesujących 
prawidłowości. Na wykresie 2 - stanowiącym zestawienie dwóch rozkładów opinii na temat stwierdzenia Kocham Szczecin (a także podstawowe statystyki) ze względu na obie wymienione zmienne odnoszące się do zakorzenienia - w syntetyczny sposób zobrazowano wyniki przeprowadzonej analizy.

Wykres 2

Rozkład opinii na temat stwierdzenia Kocham Szczecin ze względu na genezę szczecińskiej tożsamości mieszkańców w wieku 25-44 lata i ze względu na szczecińskie korzenie rodzinne

Stwierdzenie 1: Kocham Szczecin

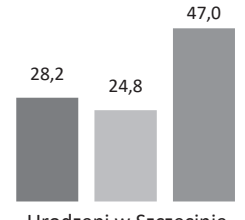

Urodzeni w Szczecinie

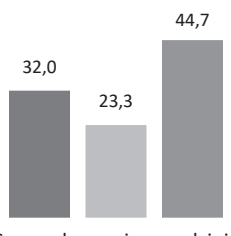

Szczec. korzenie w rodzinie

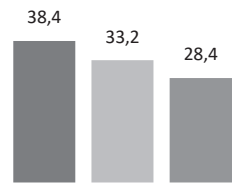

Osiedleni w Szczecinie

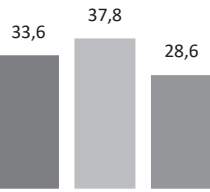

Brak szczec. korzeni w rodzinie

- Niezgadzający się z twierdzeniem $\quad$ Niezdecydowani $\quad$ Zgadzający się z twierdzeniem

Dane wyrażone w \%; $\mathrm{n}_{\text {urodzonych w Szczecinie }}=589=100 \%, \mathrm{n}_{\text {osiedlonych } w \text { Szczecinie }}=391=100 \%$

$\mathrm{n}_{\text {mających szczecińskie korzenie } \mathrm{w} \text { rodzinie }}=669=100 \%, \mathrm{n}_{\text {niemających szczecińskich korzen } \mathrm{w} \text { rodzinie }}=304=100 \%$.

Test Chi-kwadrat dla zależności między rozkładem opinii na temat stwierdzenia Kocham Szczecin a genezą szczecińskiej tożsamości

\section{Statystyki}

Chi-kwadrat Pearsona

Wskaźnik wiarygodności

Test trendu

Liczebność ważnych przypadków

Współczynnik siły związku $\mathrm{C}_{\text {kor }}$-Pearsona

Wartości
34,15
34,82
27,35
980
0,24

df

2

2

1
Poziomy istotności

0,00

0,00

0,00

Test Chi-kwadrat dla zależności między rozkładem opinii na temat stwierdzenia Kocham Szczecin a zmienną szczecińskie korzenie w rodzinie

\section{Statystyki}

Chi-kwadrat Pearsona

Wskaźnik wiarygodności

Test trendu

Liczebność ważnych przypadków

Współczynnik siły związku $\mathrm{C}_{\text {kor }}$-Pearsona

Źródło: badania własne.

$\begin{array}{ccc}\text { Wartości } & \text { df } & \text { Poziomy istotności } \\ 29,57 & 2 & 0,00 \\ 29,61 & 2 & 0,00 \\ 9,07 & 1 & 0,00 \\ 973 & & \\ 0,23 & & \end{array}$

Zarówno fakt urodzenia w Szczecinie, jak i szczecińskie korzenie w rodzinie sprzyjają postawie wyrażającej się deklarowaną miłością do miasta zamieszkania. Natomiast osiedlenie i/lub brak szczecińskich korzeni w rodzinie przeciwnie - cechuje się wprawdzie mniej wyraźnie rysującą się, a jednak przewagą opinii negatywnych nad pozytywnymi, z dużym udziałem braku zdecydowania. Stosunek do stwierdzenia Kocham Szczecin zależny jest 
zarówno od zmiennej geneza szczecińskiej tożsamości, jak i od zmiennej szczecińskie korzenie rodzinne, i to za każdym razem ze współczynnikiem ufności $1-\alpha \geq 0$,99 czyli z prawdopodobieństwem przekraczającym 99\%. Należy tu jednak uwzględnić fakt, że siła związku między zmiennymi jest raczej słaba, ponieważ różnice opinii ze względu na zakorzenienie są nie dość wyraziste, by można było mówić o dużej mocy predykcyjnej stwierdzonej zależności. Niemniej znacząca przewaga opinii pozytywnych nad negatywnymi - wśród osób urodzonych w Szczecinie oraz osób mających tu rodzinne korzenie - przy wyraźnie mniejszej (co stanowi przyczynę słabej siły związku między zmiennymi) przewadze opinii negatywnych nad pozytywnymi (i stosunkowo dużym udziale postaw niezdecydowania) wśród osób osiedlonych oraz takich, które nie mają szczecińskich korzeni rodzinnych, pozwala stwierdzić, że zakorzenienie w pewnej mierze daje uzasadnienie dla zróżnicowania opinii na temat uczuciowego kontekstu stosunku młodych, aktywnych zawodowo szczecinian do ich miasta.

Zgoła odmiennie przedstawia się kwestia postrzegania estetycznych walorów stolicy Pomorza Zachodniego przez jej mieszkańców mieszczących się w dynamicznych kategoriach wieku produkcyjnego. Tu zakorzenienie w istocie nie ma znaczenia. Niezależnie od tego, czy mamy do czynienia ze szczecinianami z urodzenia, czy z osiedlenia, jak również mającymi szczecińskie korzenie rodzinne czy ich niemającymi, urok miasta (i jego zmiany) jest postrzegany w taki sam sposób. Zdecydowana dominacja opinii głoszącej: Szczecin z roku na rok staje się piękniejszy, pozwala traktować ten element wizerunku miasta jako mający wysoce zobiektywizowany charakter. Dodatkowo godne podkreślenia jest to, że ani ze względu na płeć, ani na wiek opinie na temat estetyki miasta nie mają rozkładów uwidoczniających zależności statystyczne. Jedynie zmienna wykształcenie w istotny sposób wpływa na postrzeganie tego aspektu wizerunku miasta. W toku analizy materiału

Tabela 4

Rozkład opinii na temat stwierdzenia Szczecin z roku na rok staje się piękniejszy ze względu na poziom wykształcenia mieszkańców

\begin{tabular}{|l|c|c|c|c|c|c|}
\hline \multicolumn{2}{|c|}{ Wyszczególnienie } & \multicolumn{4}{c|}{ Kategorie wykształcenia } & \multirow{2}{*}{ Ogółem } \\
\cline { 3 - 7 } & podstawowe & zasadnicze zawodowe & średnie & wyższe & \\
\hline Niezgadzający się & liczebność & 15 & 46 & 90 & 33 & 184 \\
z twierdzeniem & $\%$ & 19,0 & 23,7 & 21,8 & 10,6 & 18,5 \\
\hline \multirow{2}{*}{ Niezdecydowani } & liczebność & 21 & 44 & 93 & 53 & 211 \\
& $\%$ & 26,6 & 22,7 & 22,6 & 17,0 & 21,2 \\
\hline Zgadzający się & liczebność & 43 & 104 & 229 & 225 & 601 \\
z twierdzeniem & $\%$ & 54,4 & 53,6 & 55,6 & 72,3 & 60,3 \\
\hline \multirow{2}{*}{ Ogółem } & liczebnośćn & 79 & 194 & 412 & 311 & 996 \\
& $\%$ & 100,0 & 100,0 & 100,0 & 100,0 & 100,0 \\
\hline
\end{tabular}

Test Chi-kwadrat dla zależności między rozkładem opinii na temat stwierdzenia Szczecin z roku na rok staje się piękniejszy a poziomem wykształcenia

\section{Statystyki}

Chi-kwadrat Pearsona

Wskaźnik wiarygodności

Test trendu

Liczebność ważnych przypadków

Współczynnik siły związku $\mathrm{C}_{\text {kor }}$-Pearsona

Źródło: badania własne.

\section{Wartości}

30,91

32,19

18,02

996

0,21
Poziomy istotności

0,00

0,00

0,00 
empirycznego ujawnił się fakt, że osoby z wyższym wykształceniem charakteryzują się większym udziałem pozytywnych opinii na temat estetyki Szczecina (a równocześnie mniejszym udziałem opinii negatywnych) niż osoby nielegitymujące się dyplomem ukończenia szkoły wyższej.

Wykres 3

\section{Rozkład opinii na temat stwierdzenia Szczecin z roku na rok staje się piękniejszy} ze względu na genezę szczecińskiej tożsamości mieszkańców w wieku 25-44 lata i ze względu na szczecińskie korzenie rodzinne

Stwierdzenie 2: Szczecin z roku na rok staje się piękniejszy

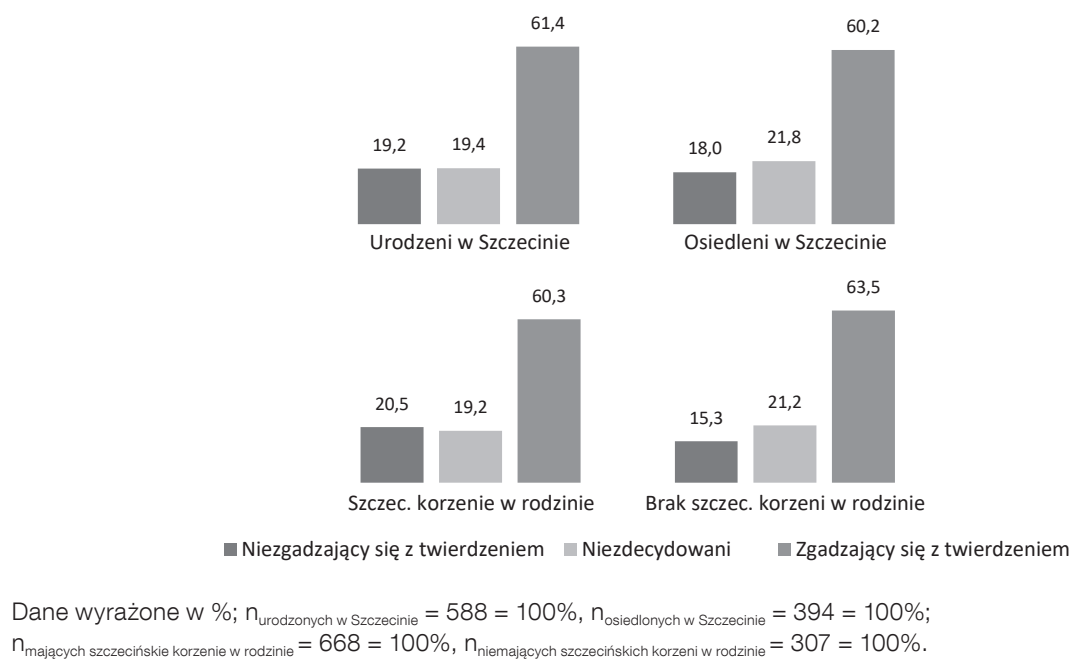

Test Chi-kwadrat dla zależności między rozkładem opinii na temat stwierdzenia Szczecin z roku na rok staje się piękniejszy a genezą szczecińskiej tożsamości

$\begin{array}{lccc}\text { Statystyki } & \text { Wartości } & \text { df } & \text { Poziomy istotności } \\ \text { Chi-kwadrat Pearsona } & 0,93 & 2 & 0,63 \\ \text { Wskaźnik wiarygodności } & 0,93 & 2 & 0,63 \\ \text { Test trendu } & 0,00 & 1 & 0,99 \\ \text { Liczebność ważnych przypadków } & 982 & & \end{array}$

Test Chi-kwadrat dla zależności między rozkładem opinii na temat stwierdzenia Szczecin z roku na rok staje się piękniejszy a zmienną szczecińskie korzenie w rodzinie

$\begin{array}{lccc}\text { Statystyki } & \text { Wartości } & \text { df } & \text { Poziomy istotności } \\ \text { Chi-kwadrat Pearsona } & 3,79 & 2 & 0,15 \\ \text { Wskaźnik wiarygodności } & 3,90 & 2 & 0,14 \\ \text { Test trendu } & 2,38 & 1 & 0,12 \\ \text { Liczebność ważnych przypadków } & 975 & & \end{array}$

Źródło: badania własne.

Reasumując, można stwierdzić, że bez względu na zróżnicowania występujące wśród szczecinian rosnący urok miasta jest podobnie postrzegany przez wszystkich, przy czym wyróżniają się tu osoby z wyższym wykształceniem. Niezależnie od stopnia zakorzenienia w Szczecinie akcentują one pozytywne zmiany estetyki miasta zdecydowanie częściej niż inni.

Inny rys obecnego w zbiorowej świadomości wizerunku Szczecina, odwołujący się do opinii na temat stwierdzenia: Szczecinianie mają więcej powodów do dumy ze swojego miasta niż powodów do wstydu, pozwala uświadomić sobie kilka interesujących spraw. 
Zasadnicze znaczenie ma tutaj przewaga pozytywnych opinii na temat Szczecina wśród osób tu osiedlonych oraz takich, które nie mają szczecińskich korzeni w rodzinach, co z kolei uzmysławia znaczenie awansu społecznego ludzi napływających z małych miejscowości do dużego miasta - stolicy województwa. Ci bowiem spośród aktywnych zawodowo młodych szczecinian częściej skłonni są dostrzegać w Szczecinie powody do dumy.

Wykres 4

Rozkład opinii na temat stwierdzenia Szczecinianie mają więcej powodów do dumy ze swojego miasta niż powodów do wstydu ze względu na genezę szczecińskiej tożsamości mieszkańców w wieku 25-44 lata i ze względu na szczecińskie korzenie rodzinne

Stwierdzenie 3: Szczecinianie mają więcej powodów do dumy ze swego miasta niż powodów do wstydu

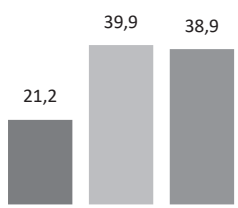

Urodzeni w Szczecinie

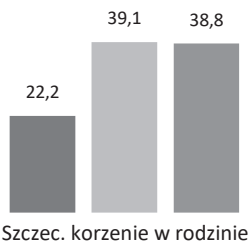

niezgadzający się z twierdzeniem

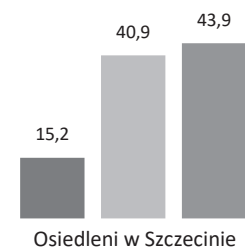

Osiedleni w Szczecinie

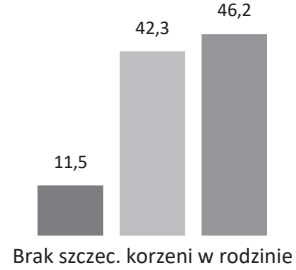

Zgadzający się z twierdzeniem

Dane wyrażone w \%; $n_{\text {urodzonych w Szczecinie }}=588=100 \%, n_{\text {osiedlonych w Szczecinie }}=394=100 \%$;

$\mathrm{n}_{\text {mających szczecińskie korzenie } \mathrm{w} \text { rodzinie }}=668=100 \%, \mathrm{n}_{\text {niemających szczecińskich korzeni w rodzinie }}=307=100 \%$.

Test Chi-kwadrat dla zależności między rozkładem opinii na temat stwierdzenia Szczecinianie mają więcej powodów do dumy ze swojego miasta niż powodów do wstydu a genezą szczecińskiej tożsamości

\section{Statystyki}

Chi-kwadrat Pearsona

Wskaźnik wiarygodności

Test trendu

Liczebność ważnych przypadków

Wartości
5,91
6.01
5,13
980

df

2

2

1
Poziomy istotności

$$
\begin{aligned}
& 0,05 \\
& 0,05 \\
& 0,02
\end{aligned}
$$

Test Chi-kwadrat dla zależności między rozkładem opinii na temat stwierdzenia Szczecinianie mają więcej powodów do dumy ze swojego miasta niż powodów do wstydu a zmienną szczecińskie korzenie w rodzinie

\section{Statystyki}

Chi-kwadrat Pearsona

Wskaźnik wiarygodności

Test trendu

Liczebność ważnych przypadków

Współczynnik siły związku $C_{\text {kor }}$-Pearsona

Źródło: badania własne.

\section{Wartości}

16,07

17,22

12,52

973

0,17
Poziomy istotności

0,00

0,00

0,00

Kolejną kwestią prowokującą do zastanowienia jest wyjątkowo wysoki udział postaw niezdecydowania. Właściwie niezależnie od zakorzenienia osiąga on poziom około 40\%. Zupełnie jednak inaczej przedstawia się wysoki udział braku jednoznacznych opinii wśród 
osób genetycznie zakorzenionych w Szczecinie przynajmniej przez fakt urodzenia niż analogicznie wysoki udział takich opinii wśród osiedleńców. W przypadku tych pierwszych brak zdecydowania w kwestii: można czy nie można być dumnym ze Szczecina, wydaje się w sposób bardziej jednoznaczny rzucać cień na wizerunek miasta. Ani bowiem wzrastanie tu od urodzenia, ani głębsze, pokoleniowe doświadczenia z życia tutaj nie stanowią podglebia dla wyrazistego stanowiska. Z drugiej zaś strony niezdecydowanie wśród szczecinian urodzonych w innych miejscowościach jest o tyle naturalne, że - jak wynika z danych - mieszkają oni w Szczecinie przeciętnie od 13,4 lat. Niezależnie jednak od zarysowanych tu odmienności należy z całą mocą wyartykułować, że skoro wyraźnie częściej niż co trzeci lokujący się w najbardziej mobilnym okresie życia nie potrafi zdecydować, czy szczecinianie mają więcej powodów do dumy ze swego miasta, czy do wstydu, a nadto wcale niemały jest udział opowiadających się po stronie większej ilości powodów do wstydu, to trudno nie ulec narzucającemu się wnioskowi, że fakt ten ujawnia słabość wizerunku Szczecina oraz stwarza zagrożenie dla jego rozwoju.

Lekko prowokacyjne stwierdzenie: Na przestrzeni lat Szczecin staje się coraz bardziej prowincjonalnym miastem - ogniskujące nadzieje szczecinian na życie w rozwijającym się gospodarczo, prężnym ośrodku życia społecznego i kulturalnego oraz doświadczenia codzienności - stwarza pretekst dla swoistej syntezy w myśleniu o mieście, prowadzącej do ekspozycji przekonania (lub przynajmniej wiary), że „sprawy idą w dobrą stronę...” albo kompensacji rozczarowań. Jakże wymowną postać przyjmują rozkłady opinii szczecinian w tym względzie widziane z perspektywy zakorzenienia.

Brak zależności między rozkładem opinii na temat treści stwierdzenia a obiema zmiennymi odnoszącymi się do zakorzenienia potwierdza konstatację, że szczecinianie bez względu na to, czy urodzeni w Szczecinie, czy osiedleni tu, oraz bez względu na to, czy mający szczecińskie korzenie rodzinne, czy ich niemający, tak samo postrzegają ten aspekt wizerunku Szczecina. Więcej jeszcze - również zmienne płci, wieku i wykształcenia nie wpływają w sposób istotny statystycznie na opinie na ten temat. Choć zatem nie zachodzi statystyczny związek między zmiennymi, znaczenie zakorzenienia ujawnia się w nieco innym kontekście. Wśród osób osiedlonych w Szczecinie oraz takich, które nie mają szczecińskich korzeni rodzinnych, różnice udziałów opinii pozytywnych i negatywnych są wyraźnie większe (na rzecz pozytywnych) niż w przypadku szczecinian z urodzenia oraz tych, którzy mają tu korzenie rodzinne. Znowu zatem mamy do czynienia, jak się wydaje, z echem osiedlenia wydobywającym się z kontrastowości doznawania wielkiego miasta jako nowego miejsca życia w porównaniu z obszarami pochodzenia. Z drugiej strony skoro we wszystkich kategoriach mieszkańców jest tak dużo niezdecydowanych w kwestii: Na przestrzeni lat Szczecin staje się coraz bardziej prowincjonalnym miastem, to peryferyzacja Szczecina jawi się jako ważki temat do dyskusji. Innymi słowy, jeśli tak wielu ludzi, konfrontując swoje oczekiwania i nadzieje związane z życiem w stolicy Pomorza Zachodniego z codziennym doświadczeniem, nie potrafi rozsądzić, czy Szczecin staje się prowincją, czy nie, to można wysnuć stąd wniosek, że widzą tu problem, czyli w istocie dostrzegają wskaźniki peryferyzacji. Oznacza to dalej, że prowokacja zawarta w zastosowanym stwierdzeniu paradoksalnie udała się - synteza w myśleniu o mieście nie doprowadza, w przypadku tej licznej części szczecinian, do sprzeciwu lub do wyrażenia niezadowolenia z obrotu spraw poprzez zgodę z tym stwierdzeniem, a jedynie pozostawia ich w niemym niezdecydowaniu. 
Rozkład opinii na temat stwierdzenia Na przestrzeni lat Szczecin staje się coraz bardziej prowincjonalnym miastem ze względu na genezę szczecińskiej tożsamości mieszkańców w wieku 25-44 lata i ze względu na szczecińskie korzenie rodzinne

Stwierdzenie 4: Na przestrzeni lat Szczecin staje się coraz bardziej prowincjonalnym miastem
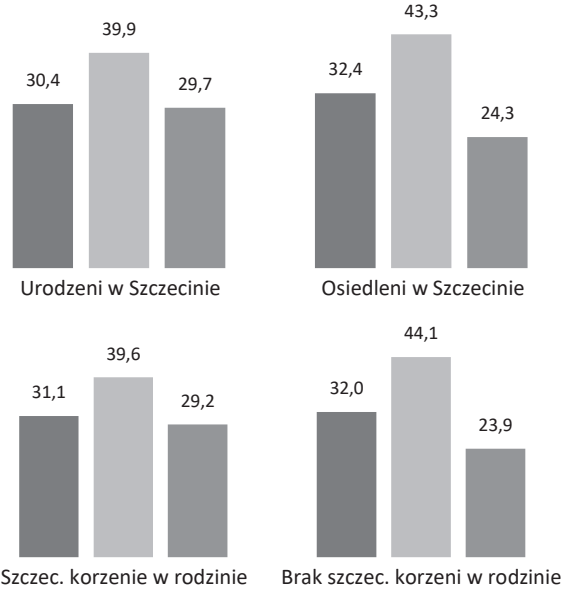

$$
\text { - Niezgadzający się z twierdzeniem @ Niezdecydowani } \quad \text { Zgadzający się z twierdzeniem }
$$

Dane wyrażone w \%; $\mathrm{n}_{\text {urodzonych w Szczecinie }}=589=100 \%, \mathrm{n}_{\text {osiedlonych } w \text { Szczecinie }}=395=100 \%$;

$\mathrm{n}_{\text {mających szczecińskie korzenie } \mathrm{w} \text { rodzinie }}=671=100 \%, \mathrm{n}_{\text {niemających szczecińskich korzeni } \mathrm{w} \text { rodzinie }}=306=100 \%$.

Test Chi-kwadrat dla zależności między rozkładem opinii na temat stwierdzenia Na przestrzeni lat Szczecin staje się coraz bardziej prowincjonalnym miastem a genezą szczecińskiej tożsamości

$\begin{array}{lccc}\text { Statystyki } & \text { Wartości } & \text { df } & \text { Poziomy istotności } \\ \text { Chi-kwadrat Pearsona } & 3,48 & 2 & 0,18 \\ \text { Wskaźnik wiarygodności } & 3,51 & 2 & 0,17 \\ \text { Test trendu } & 2,22 & 1 & 0,14 \\ \text { Liczebność ważnych przypadków } & 984 & & \end{array}$

Test Chi-kwadrat dla zależności między rozkładem opinii na temat stwierdzenia Na przestrzeni lat Szczecin staje się coraz bardziej prowincjonalnym miastem a zmienną szczecińskie korzenie w rodzinie

\section{Statystyki}

Chi-kwadrat Pearsona

Wskaźnik wiarygodności

Test trendu

Liczebność ważnych przypadków

Wartości
3,27
3,31
1,39
977

Źródło: badania własne.

\section{Poziomy istotności}

0,20

0,19

0,24

Ostatni element, stanowiący inferencyjny wskaźnik ogólnie pojmowanego obrazu Szczecina w świadomości jego mieszkańców, zawiera w treści stwierdzenia: Wolałabym/wolałbym mieszkać w innym niż Szczecin miejscu Polski lub poza Polską, ważną supozycję odwołującą się do głębszych niż tylko opinia na temat wizerunku miasta pokładów postaw szczecinian. Odczytać w niej można kontekst zadowolenia z zamieszkiwania w mieście otwierający horyzont refleksji nad tym esencjonalnym aspektem szczecińskości. Wszystko, co wiąże się z zamieszkiwaniem w dobrym do życia miejscu, takim, o którym bez namysłu mówi się „moje miasto”, w którym zauważa się możliwości samorozwoju, dostrzega oraz nade wszystko rozumie się i akceptuje różnorodność wzorców realizacji aspiracji 
i celów życiowych, daje poczucie satysfakcji i bezpieczeństwa w myśleniu o przyszłości w tym mieście. Natomiast jakiekolwiek deficyty w tym zakresie powodują, że doświadczenie nieadekwatności miejsca, w którym się żyje, staje się lejtmotywem jego obrazu w świadomości. A zatem deklaracja niechęci do zamieszkiwania w Szczecinie stanowi zarówno rysę na zbiorowym wizerunku miasta, jak i przejaw braku przekonania, że można w nim żyć tak, jak się chce i jak się marzy.

Wykres 6

Rozkład opinii na temat stwierdzenia Wolałabym/wolałbym mieszkać w innym niż Szczecin miejscu Polski lub poza Polską ze względu na genezę szczecińskiej tożsamości mieszkańców w wieku 25-44 lata i ze względu na szczecińskie korzenie rodzinne

Stwierdzenie 5: Wolałabym/wolałbym mieszkać w innym niż Szczecin miejscu Polski lub poza Polską

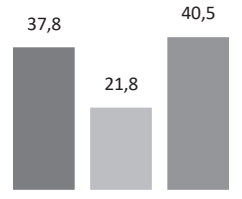

Urodzeni w Szczecinie

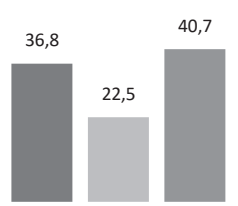

Szczec. korzenie w rodzinie

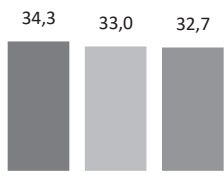

Osiedleni w Szczecinie

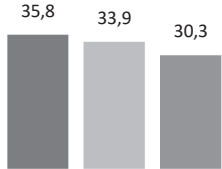

Brak szczec. korzeni w rodzinie

\footnotetext{
ఐ Niezgadzający się z twierdzeniem $\quad$ Niezdecydowani $\quad$ Zgadzający się z twierdzeniem

Dane wyrażone w \%; $n_{\text {urodzonych w Szczecinie }}=588=100 \%, n_{\text {osiedlonych } w \text { Szczecinie }}=394=100 \%$;

$\mathrm{n}_{\text {mających szczecińskie korzenie } \mathrm{w} \text { rodzinie }}=668=100 \%, \mathrm{n}_{\text {niemających szczecińskich korzeni } \mathbf{w} \text { rodzinie }}=307=100 \%$.
}

Test Chi-kwadrat dla zależności między rozkładem opinii na temat stwierdzenia Wolałabym/wolałbym mieszkać w innym niż Szczecin miejscu Polski lub poza Polską a genezą szczecińskiej tożsamości

\section{Statystyki}

Chi-kwadrat Pearsona

Wskaźnik wiarygodności

Test trendu

Liczebność ważnych przypadków

Współczynnik siły związku $\mathrm{C}_{\text {kor }}$-Pearsona

Wartości
15,88
15,72
0,58
982
0,17

Test Chi-kwadrat dla zależności między rozkładem opinii na temat stwierdzenia Wolałabym/wolałbym mieszkać w innym niż Szczecin miejscu Polski lub poza Polską a zmienną szczecińskie korzenie w rodzinie

\section{Statystyki}

Chi-kwadrat Pearsona

Wskaźnik wiarygodności

Test trendu

Liczebność ważnych przypadków

Współczynnik siły związku $\mathrm{C}_{\text {kor }}$-Pearsona

Źródło: badania własne.

$\begin{array}{ccc}\text { Wartości } & \text { df } & \text { Poziomy istotności } \\ 16,70 & 2 & 0,00 \\ 16,47 & 2 & 0,00 \\ 2,53 & 1 & 0,11 \\ 975 & & \\ 0,17 & & \end{array}$

Analizowane stwierdzenie stanowi również rodzaj swoistego testu dla jakości zakorzenienia, a w tym względzie - znaczenia genetycznych związków ze Szczecinem dla siły związania z miastem. O ile bowiem ogólny rozkład opinii na jego temat cechował się niemal dokładną równowagą deklaracji pozytywnych i negatywnych, o tyle zmienne geneza 
szczecińskiej tożsamości oraz szczecińskie korzenie w rodzinie wprowadzają tu pewne zróżnicowania. Dość wskazać, że wyniki przeprowadzonej analizy świadczą o istotnych statystycznie związkach między opiniami formułowanymi w stosunku do treści stwierdzenia a obiema zmiennymi zakorzenienia.

Przy raczej małej sile związków stochastycznych można traktować zmienne zakorzenienia jako co prawda niemające dużego znaczenia dla wyjaśniania zróżnicowań opinii na temat stwierdzenia: Wolałabym/wolałbym mieszkać w innym niż Szczecin miejscu Polski lub poza Polską, niemniej z pewnych względów istotne dla analizy stosunku młodych, aktywnych zawodowo szczecinian do miasta w kontekście możliwości postrzegania go jako „własnego miejsca na ziemi”. Choć niezaprzeczalny jest fakt, że zarówno wśród urodzonych, jak i osiedlonych w Szczecinie bardzo podobny jest udział (nieco powyżej 60\%) tych, którzy nie deklarują sprzeciwu wobec treści stwierdzenia - i analogicznie wśród osób mających szczecińskie korzenie w rodzinach i tych, którzy nie mają pokoleniowych związków z miastem - jednak nie sposób zaniechać spojrzenia z odsłaniającej się, odmiennej perspektywy. Jej fundamentalny walor poznawczy pozwala dostrzec znaczenie zakorzenienia nie tyle dla wyjaśniania zróżnicowań opinii na temat treści stwierdzenia, ile dla uzmysłowienia warunku sine qua non rozumienia tożsamości szczecinian, czyli podstaw dla przekonania, że właśnie tutaj chce się żyć... albo odwrotnie - że tutaj się nie da żyć... Jeśli więc podjąć interpretację z tej perspektywy, to ujawni się szczególne - domagające się zaakcentowania - znaczenie faktu, że udział osób deklarujących wolę zamieszkiwania poza Szczecinem jest istotnie większy w kategoriach urodzonych tu, jak również tych, którzy mają genetyczne związki rodzinne z miastem, niż wśród osiedleńców oraz niezwiązanych z nim pokoleniowo. W obliczu tak przedstawiającej się prawidłowości trudno oprzeć się osobliwej refleksji. Otóż głębsze związki z miastem - cechujące się albo wieloletnimi doświadczeniami biograficznymi, albo partycypowaniem w przekazie doświadczeń życia w Szczecinie jednego lub dwóch pokoleń przodków - w stosunkowo ograniczonym zakresie wpływają na przywiązanie do miasta. Około czterdziestoprocentowy udział w tych kategoriach zmiennych zakorzenienia, które definiują genetyczny związek ze stolicą Pomorza Zachodniego, wyrażających preferencję zamieszkiwania gdzieś indziej, świadczy aż nadto dobitnie o rozmiarach deficytu więzi z miastem. W przypadku tych szczecinian ani fakt wzrastania i dojrzewania w warunkach życia, pracy, kultury, wzorów spędzania czasu wolnego, jakie panują w Szczecinie, ani całokształt doświadczeń oraz osiągnięć rodziców czy dziadków nie stanowią dość mocnej zapory dla myśli o tym, że wolałoby się żyć w innym miejscu. Nie są one wystarczającą przeciwwagą negatywnych odczuć w bilansie tego, co ze Szczecinem wiąże, i tego, co od niego odstręcza. Dla tych mieszkańców Szczecin może z czasem stać się pozostawionym domem rodzinnym, gniazdem, z którego się uleciało w poszukiwaniu nowego miejsca do życia...

Z kolei udział analogicznej postawy wśród osób, których lokalna tożsamość nie jest określona przez urodzenie czy związki pokoleniowe, okazuje się istotnie mniejszy, oscylując wokół 30\%. Niemniej również tym razem można powiedzieć, że rozmiary rozluźnionych związków z miastem nie napawają optymizmem, przywodząc na myśl konkluzję o wcale dużym udziale rozczarowania miejscem osiedlenia wśród młodych, aktywnych ludzi, którzy - dążąc do osiągnięcia życiowych celów - wybrali Szczecin. W ich przypadku to miasto może się okazać jedynie miejscem tymczasowym, a zamieszkiwanie w nim - okresem niespełnionych nadziei i niezbyt udanych starań o możliwość pełnej identyfikacji jako szczecinian... 


\section{O mieszkańcach Szczecina - elementy zbiorowej autopercepcji}

Bardziej szczegółowy ogląd opinii na temat Szczecina pozwala z jednej strony odsłonić i uzmysłowić sobie stymulujący, jak również destymulujący (dla rozwoju lokalnej tożsamości) charakter podstawowych aspektów wizerunku miasta, z drugiej zaś uchwycić i scharakteryzować zasadnicze konteksty tych opinii, które w ujęciu ogólnym pokazały osłabione związki szczecinian z ich miejscem zamieszkania. Pierwszym wymiarem bardziej szczegółowego oglądu społecznego wizerunku Szczecina są ludzie - mieszkańcy miasta. W badaniu zakwalifikowano do analizy trzy odnoszące się do tego wymiaru sformułowania, na których temat zostały wyrażone opinie młodych, aktywnych zawodowo szczecinian. Stwierdzenie pierwsze, zawierające - fundamentalny dla rozumienia podjętej problematyki - kontekst autoidentyfikacji: Mieszkaniec Szczecina to brzmi dumnie; stwierdzenie drugie,

Wykres 7

Stosunek do mieszkańców Szczecina - zestawienie rozkładów opinii (\%)

Mieszkaniec Szczecina to brzmi dumnie

Zdecydowanie nie do zdecydowanie tak

Raczej nie do raczej tak

Trudno powiedzieć

Brak danych

Negatywny stosunek Pozytywny stosunek

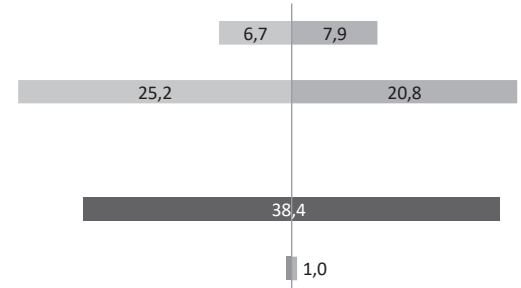

Gdy myślę ogólnie o mieszkańcach Szczecina, mogę o nich powiedzieć więcej dobrego niż złego

Zdecydowanie nie do zdecydowanie tak

Raczej nie do raczej tak

Trudno powiedzieć

Brak danych

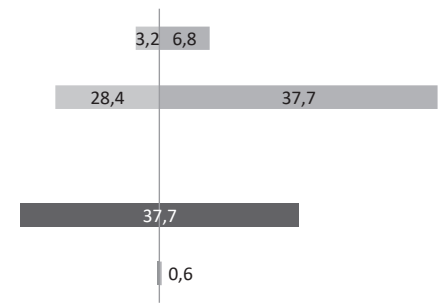

Szczecinianom brakuje wzajemnej więzi

Zdecydowanie tak do zdecydowanie nie

Raczej tak do raczej nie

Trudno powiedzieć

Brak danych

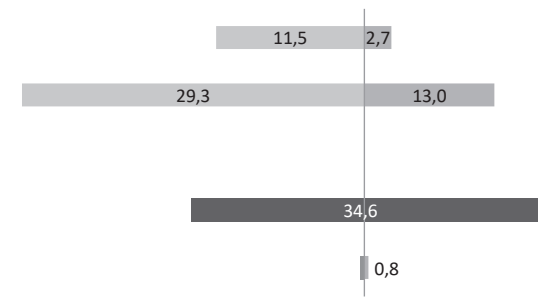

$n=1003=100 \%$.

Źródło: badania własne. 
eksponujące afektywny komponent postawy wobec społeczeństwa stolicy Pomorza Zachodniego: Gdy myślę ogólnie o mieszkańcach Szczecina, mogę o nich powiedzieć więcej dobrego niż złego; stwierdzenie trzecie, odwołujące się do często podnoszonego, charakterystycznego dla Szczecina zagadnienia ograniczonych więzi lokalnych w przestrzeni miasta: Szczecinianom brakuje wzajemnej więzi. Rozkłady opinii na temat treści wymienionych stwierdzeń zestawiono na wykresie 7.

Warto w tym miejscu przywołać słowa Zygmunta Baumana (2006), dociekającego nieoczywistej, skłaniającej do wielkiego wysiłku poznawczego istoty społeczeństwa. Pisze on, parafrazując słowa C. Wrighta Millsa:

(...) praca wyobraźni socjologicznej polega na dokonywaniu obustronnego przekładu: opowieści prywatnej na publiczną i na odwrót, a więc tłumaczeniu indywidualnie i prywatnie podejmowanych problemów na sferę publicznych, zbiorowo podejmowanych zagadnień, oraz interesów publicznych na strategię życiową jednostki (...) surowcem, jaki przetwarza wyobraźnia socjologiczna, jest ludzkie doświadczenie. Jej końcowy produkt nazywany „rzeczywistością społeczną” to forma wytopiona z rudy doświadczenia (s. 33).

Zestawienie opinii uczestników badania na temat wiązki elementów egzemplifikujących zbiorową autoidentyfikację istotnej kategorii szczecinian pozwala uświadomić sobie i wyartykułować kilka godnych rozwagi prawidłowości wiążących obszar indywidualnych problemów codzienności z publiczną sferą społecznego dyskursu na temat szczecińskości. Nie sposób bowiem nie nadać właściwych akcentów - wyłaniającym się z formy utrwalonych wzorów tożsamości lokalnej - postaciom szczecińskiej rzeczywistości społecznej. Akcent pierwszy: wszyscy deklarujący zgode ze stwierdzeniem Mieszkaniec Szczecina to brzmi dumnie (28,7\%) równocześnie wyrażają pozytywne opinie na temat dwóch, omawianych wcześniej, zbliżonych pod względem treści stwierdzeń ogólnych, czyli twierdzą, że szczecinianie mają więcej powodów do dumy ze swego miasta niż powodów do wstydu (cały udział pozytywnych opinii - 40,4\%) oraz że kochają Szczecin (cały udział pozytywnych opinii - 39,2\%). Spojrzenie z przeciwnej perspektywy pokazuje istotne statystycznie rozbieżności: część szczecinian deklarujących, że mieszkańcy ich miasta mają więcej powodów do dumy niż do wstydu ze Szczecina oraz część przystających na treść stwierdzenia o ich miłości do miasta, jednak nie jest w stanie sformułować opinii świadczącej o najwyższym stopniu internalizacji lokalnej tożsamości, że samo bycie szczecinianinem to powód do dumy ${ }^{4}$. Akcent drugi: niemal dokładna równowaga opinii pozytywnych i negatywnych $(28,7 \%$ do $31,9 \%)$ oraz przewaga postaw niezdecydowania $(38,4 \%)$ w kwestii dumy z tego, że się jest szczecinianinem daje wymowny wyraz poziomowi społecznej autoidentyfikacji młodych, najaktywniejszych życiowo i zawodowo mieszkańców miasta. Akcent trzeci: wbrew charakterystycznemu w stolicy Pomorza Zachodniego, niemal tak samo jak paprykarz szczeciński, wszechobecnemu na ulicy narzekactwu młodzi, aktywni zawodowo mieszkańcy miasta widzą w tym społeczeństwie więcej dobrego niż złego. Jeśli pominąć (zawiesić) czysto psychologiczny, raczej mało predykcyjny i inspirujący kontekst stwierdzenia: Gdy myślę ogólnie o mieszkańcach Szczecina, moge o nich powiedzieć więcej dobrego niż złego, to można mieć nadzieję, dostrzec szansę na wypracowanie pozytywnych przedstawień zbiorowych na temat miasta. Należy jednak z całą mocą podkreślić, że mrzonką

\footnotetext{
${ }^{4}$ Wskaźnik ten ma wyższą moc odrzucania $\left(\mathrm{MO}_{\mathrm{wl}}=0,75\right)$ niż wskaźniki miłość do Szczecina $\left(\mathrm{MO}_{\mathrm{wI}}=0,55\right)$ oraz przewaga powodów do dumy ze Szczecina nad powodami do wstydu $\left(\mathrm{MO}_{w 1}=0,49\right)$. Oznacza to, że osoby deklarujące dumę z bycia szczecinianinem charakteryzuja się najwyższym stopniem lokalnej tożsamości, gdyż w tej kategorii znajduje się najmniejsza liczba nieprzejawiających którejś z cech wysokiego poziomu internalizacji szczecińskości (por. Nowak, 1985, s. 178).
} 
jest wiara, iż ludzie ci zrobią to sami. Bez rozważnej i wytrwałej pracy podmiotów powołanych do odpowiedzialności za miasto, a także istotnych lokalnych środowisk pełna społeczna synergia nie wyzwoli się w jakimś akcie witalnego impulsu. Akcent czwarty: szczecinianie mają pewien kompleks związany z więzią lokalną. Choć kochają Szczecin, choć miasto im się podoba, często zachowują się tak, jakby nie identyfikowali siebie jako ludzi tworzących wspólne dzieło... W tym kontekście szczecińskość sprawia wrażenie jakości quasi-emergentnej. Szczególnie wyraźnie przejawia się to w myśleniu o sobie w odniesieniu do zbiorowości jako „kompletnego” społecznego bytu. Co prawda, w codziennym dyskursie na temat miasta i jego mieszkańców obecne jest „szczecińskie my”, ale nie jest ono „jakieś” - nie przyjmuje postaci swoich symbolicznych egzemplifikacji. Trudno jest wskazać w Szczecinie coś takiego, co byłoby traktowane przez mieszkańców miasta jako „niepowątpiewalnie nasze" (dokonane wspólnie), tak bardzo szczecińskie, że niepowtarzalne i charakterystyczne. Warto w tym miejscu wskazać, że reprezentowani w badaniu szczecinianie, należący do dynamicznych kategorii wieku produkcyjnego, zapytani o to, z czego w Szczecinie mogą być dumni, co stanowi przedmiot ich zadowolenia, w 14,4\% wskazali atuty miasta niestanowiące walorów historycznych lub geograficznych (związanych z położeniem) czy wreszcie przyrodniczych. Najczęściej wskazywali Arenę Azoty, dużą liczbę hipermarketów w centrum miasta, poprawę (modernizację) estetyki ulic oraz konkretnych budynków (Urząd Miasta), uczelnie Szczecina, Trasę Zamkową (lub ogólnie wjazd do Szczecina), Filharmonię im. Mieczysława Karłowicza, nowy dworzec PKP, deptak Bogusława, rower miejski i ścieżki rowerowe, Tall Ships Races, Dni Morza, ofertę kulturalną miasta, szczecińskie paszteciki, a rzadziej ogród „Różanka” i obiekt artystyczny „Fryga”. Z kolei położenie geograficzne, dużą ilość terenów zielonych i zabytki wskazuje 20\% młodych, aktywnych zawodowo szczecinian. Natomiast 1\% formułowanych swobodnie wypowiedzi stanowia wskazania na ludzi (mieszkańców miasta) jako źródło zadowolenia

Dodatkowego wzmocnienia dla sformułowanych tu ustaleń dostarcza odwołanie się do uwag poczynionych przez cytowanego już wcześniej Pawła Kubickiego, który w swej refleksji nad wynikami badań porównujących wizerunki Wrocławia i Szczecina przytacza fragment artykułu Artura Liskowackiego Szczecin z widokiem na morze:

Mit miasta na rubieżach, jakby to była granica Interioru, nie brama do Europy (...) w przeciwieństwie do naszych Kresów, gdzieśmy zostawili serce - nie ma nic, co warte by było uwagi i fatygi podroży. Ten mit nie tylko nie umarł wraz z PRL-em, ale w Unii Europejskiej, która przyniosła otwarcie na świat - paradoksalnie - zyskał nowe życie. Widmowe właśnie, a raczej mgliste, amorficzne (za: Kubicki, 2016, s. 329).

W komentarzu do przytoczonych słów autor książki Wynajdywanie miejskości odnosi się do dzieła, które ma stanowić samą kwintesencję „nowego Szczecina”, zarówno wizję miasta, jak i przedmiot identyfikacji społecznej jego mieszkańców. Z przejmującą jednoznacznością pisze on:

Przykładem takiej mglistej i widmowej narracji jest promowana dużymi nakładami środków oficjalna marka miasta Floating Garden 2050. Zgodnie z tą koncepcją Szczecin ma stać się miastem o wysokiej jakości życia, wykorzystującym, zdaniem autorów, swój największy atut: wodę i zieleń. Tym idealnym miastem ma się stać w 2050 roku. Problem tylko w tym, że z tego dokumentu nie można się niczego dowiedzieć zarówno o przeszłości miasta, jak i jego teraźniejszości, tak jakby miasto istniejące w konkretnej rzeczywistości było fantomem bez tożsamości, którą można w dowolny sposób stworzyć w przyszłości. Narracja ta została niemal zupełnie odrzucona przez mieszkańców (Kubicki, 2016, s. 329). 
Rozkład opinii na temat stwierdzenia Mieszkaniec Szczecina to brzmi dumnie ze względu na genezę szczecińskiej tożsamości mieszkańców w wieku 25-44 lata i ze względu na szczecińskie korzenie rodzinne

Stwierdzenie 1: Mieszkaniec Szczecina to brzmi dumnie

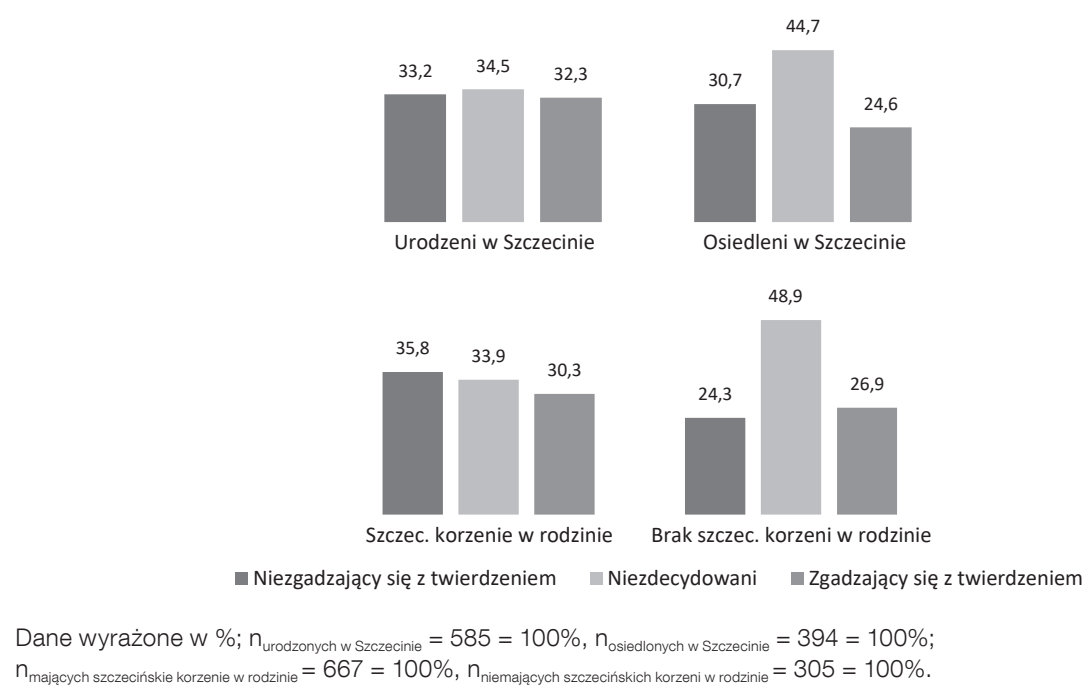

Test Chi-kwadrat dla zależności między rozkładem opinii na temat stwierdzenia Mieszkaniec Szczecina to brzmi dumnie a genezą szczecińskiej tożsamości

$\begin{array}{lccc}\text { Statystyki } & \text { Wartości } & \text { df } & \text { Poziomy istotności } \\ \text { Chi-kwadrat Pearsona } & 11,47 & 2 & 0,00 \\ \text { Wskaźnik wiarygodności } & 11,49 & 2 & 0,00 \\ \text { Test trendu } & 1,05 & 1 & 0,31 \\ \text { Liczebność ważnych przypadków } & 979 & & \\ \text { Współczynnik siły związku C } \text { kor }^{-P e a r s o n a} & 0,14 & & \end{array}$

Test Chi-kwadrat dla zależności między rozkładem opinii na temat stwierdzenia Mieszkaniec Szczecina to brzmi dumnie a zmienną szczecińskie korzenie w rodzinie

$\begin{array}{lccc}\text { Statystyki } & \text { Wartości } & \text { df } & \text { Poziomy istotności } \\ \text { Chi-kwadrat Pearsona } & 21,68 & 2 & 0,00 \\ \text { Wskaźnik wiarygodności } & 21,67 & 2 & 0,00 \\ \text { Test trendu } & 2,28 & 1 & 0,13 \\ \text { Liczebność ważnych przypadków } & 972 & & \\ \text { Współczynnik siły związku C } \text { kor }^{-P e a r s o n a} & 0,19 & & \end{array}$

Źródło: badania własne.

Spojrzenie na opinie na temat szczecinian z perspektywy zmiennych zakorzenienia pozwala rozważyć znaczenie tego istotnego aspektu szczecińskości dla zbiorowej autopercepcji. Mamy zatem z jednej strony takie uwarunkowania, jak wzrastanie i dojrzewanie wśród mieszkańców miasta albo więcej jeszcze - jedno- lub dwupokoleniowe kształtowanie jego społecznej istoty, a z drugiej strony okoliczności adaptacji oraz (w dłuższej perspektywie) asymilacji i ewentualnie integracji z otoczeniem o niejednokrotnie odmiennych niż w społecznościach odpływu wzorach aktywności zawodowej, spędzania wolnego czasu, kulturze i innych cechach. 
Jak już wcześniej stwierdzono, poczucie dumy z bycia mieszkańcem Szczecina należy (obok deklaracji miłości do miasta oraz przekonania, że szczecinianie mają więcej powodów do dumy ze swego miasta niż do wstydu) do „najsilniejszych” wskaźników lokalnej tożsamości. Można wręcz wskazać na płaszczyznę tożsamości nie tylko odczuwanej, lecz także świadomej (i to w jej aktywnej postaci), a mianowicie w formie akceptacji szczecińskości jako „właściwości wspólnej”, za pomocą której można (i chętnie się to robi) odróżnić się od innych. Jak zatem łatwo dostrzec, określenia: szczecinianin z urodzenia, szczecinianin z osiedlenia, szczecinianin mający rodzinne korzenie w mieście, szczecinianin niemający rodzinnych korzeni w mieście, odnoszące się do faktów zaistniałych (czy zapoczątkowanych) w stosunkowo odległym w czasie, a przy tym przynajmniej w pewnej części niezależnych od woli, mogą - ale nie muszą - cechować się akceptacją tożsamości lokalnej. Natomiast określenie szczecinianin z przekonania jest niejako tej akceptacji przypisane. W kontekście omawianych tu badań zgoda ze stwierdzeniem: Mieszkaniec Szczecina to brzmi dumnie, stanowi najbardziej jasny i jednoznaczny wyraz takiej właśnie tożsamości.

Założenie „filtra zakorzenienia” na ten wymiar autoidentyfikacji szczecinian, który ufundowany jest na najbardziej osobistej podstawie definicji siebie jako członka wspólnoty, wyrażającej się w ekspresji przynależności (ewentualnie jej braku bądź wręcz zaprzeczeniu), uwidocznia cokolwiek odmienne oddziaływanie czynników „wyrastania” ze społecznej tkanki miasta oraz „wrastania” w nią. Jeśli uwzględnić aspekt czasu w dociekaniach istoty oddziaływania tych jakże różnych czynników (a wydaje się to nieodzowne dla uchwycenia najbardziej zasadniczej perspektywy oglądu sposobów postrzegania siebie jako szczecinian), to prosty do zrozumienia okaże się fakt, że wśród osób osiadłych w Szczecinie dominują postawy niezdecydowania i więcej jeszcze - pod tym względem najwyraźniej różnią się oni od urodzonych w stolicy Pomorza Zachodniego. Otóż o ile pod względem średniej wieku obydwie wyróżnione kategorie praktycznie się nie różnią, o tyle już pod względem lat życia w Szczecinie ujawniają się wyraziste różnice.

Tabela 5

Średnia liczba lat bycia szczecinianinem wśród formułujących opinie na temat treści stwierdzenia Mieszkaniec Szczecina to brzmi dumnie ze względu na genezę szczecińskiej tożsamości mieszkańców w wieku 25-44 lata

\begin{tabular}{|l|c|c|}
\multicolumn{1}{|c|}{ Wyszczególnienie } & $\begin{array}{c}\text { Urodzeni } \\
\text { w Szczecinie }\end{array}$ & $\begin{array}{c}\text { Osiedleni } \\
\text { w Szczecinie }\end{array}$ \\
\hline Średnia wieku & 33,7 & 34,5 \\
\hline Średnia liczba lat (ogółem) bycia szczecinianinem & 33,7 & 14,3 \\
\hline $\begin{array}{l}\text { Średnia liczba lat bycia szczecinianinem wśród wyrażających opinię } \\
\text { na temat treści stwierdzania Mieszkaniec Szczecina to brzmi dumnie }\end{array}$ & & \\
$\quad$ wśród osób niezgadzających się z treścią stwierdzenia & 33,9 & 15,5 \\
wśród niezdecydowanych & 33,5 & 13,6 \\
wśród osób zgadzających się z treścią stwierdzenia & 33,5 & 14,2 \\
\hline
\end{tabular}

Źródło: badania własne.

Osoby osiedlone przejawiające postawę niezdecydowania w odniesieniu do treści analizowanego stwierdzenia pozostają mieszkańcami Szczecina przeciętnie ponaddwukrotnie krócej - a jeśli dodatkowo uwzględnić wartość mediany, która wynosi w tej kategorii 
dwanaście lat, to okazuje się, że połowa niezdecydowanych osiedleńców mieszka tu bez mała trzykrotnie krócej niż rodowici szczecinianie ${ }^{5}$.

Podobnie przedstawia się specyfika różnic między tymi, którzy mają szczecińskie korzenie w rodzinach, a osobami niemającymi takiego zakorzenienia w mieście.

Tabela 6

Średnia liczba lat bycia szczecinianinem wśród formułujących opinie na temat treści stwierdzenia Mieszkaniec Szczecina to brzmi dumnie ze względu na szczecińskie korzenie rodzinne mieszkańców w wieku 25-44 lata

\begin{tabular}{|l|c|c|}
\hline \multicolumn{1}{|c|}{ Wyszczególnienie } & $\begin{array}{c}\text { Szczecińskie } \\
\text { korzenie w rodzinach }\end{array}$ & $\begin{array}{c}\text { Brak szczecińskich } \\
\text { korzeni w rodzinach }\end{array}$ \\
\hline Średnia wieku & 33,9 & 34,3 \\
\hline Średnia liczba lat (ogółem) bycia szczecinianinem & 27,3 & 12,4 \\
\hline Średnia liczba lat bycia szczecinianinem wśród wyrażających opinię & & \\
na temat treści stwierdzania Mieszkaniec Szczecina to brzmi dumnie & & 11,9 \\
wśród osób niezgadzających się z treścią stwierdzenia & 27,5 & 12,2 \\
wśród niezdecydowanych & 27,9 & 13,5 \\
\hline wśród osób zgadzających się z treścią stwierdzenia & 25,7 & \\
\hline
\end{tabular}

Źródło: badania własne.

Dwukrotnie krótszy przeciętny czas pozostawania szczecinianami wśród osób niemających szczecińskich korzeni w porównaniu z osobami zakorzenionymi pokoleniowo w mieście pozwala twierdzić, że mamy do czynienia z postawami ludzi, którzy znajdują się jeśli nie nadal w fazie adaptacji do warunków życia w Szczecinie, to co najwyżej u początków fazy asymilacji. Dodatkowo nadmienić wypada, że wartość mediany (Me = 11,5 lat) i w tym przypadku jest mniejsza niż wartość średniej arytmetycznej, czyli połowa osób wyrażających postawę niezdecydowania w kwestii dumy z bycia szczecinianami (wśród niemających rodzinnych korzeni w tym mieście) mieszka tu co najwyżej 11,5 roku. Więcej jeszcze - wysoko dodatnia wartość współczynnika skośności świadczy o tym, że większość osób pozostaje szczecinianami krócej niż wskazuje średnia ${ }^{6}$.

Zagadnieniem odrębnym jest udział opinii pozytywnych i negatywnych na temat omawianego stwierdzenia. Ze względu na brak danych porównawczych z innych miast Polski trudno jest nadać interpretacji uzyskanych wyników walor obiektywności. Wydaje się jednak, że około trzydziestoprocentowy udział opinii wyrażających zgodę z treścią stwierdzenia wśród genetycznie zakorzenionych w Szczecinie i ledwie kilka punktów procentowych niższy udział wśród osiedlonych tu oraz wśród niepowiązanych z miastem pokoleniowo stanowią niemały kapitał dla mądrych działań na rzecz kreowania dobrego wizerunku stolicy Pomorza Zachodniego i pozytywnej narracji szczecińskości. Z kolei równowaga lub nie bardzo wyraźna przewaga opinii negatywnych nad pozytywnymi stanowi kolejny probierz niezadowolenia i rozczarowania tym, jak Szczecin jawi się jego młodym, aktywnym zawodowo mieszkańcom, usilnie potrzebującym powodów do dumy z bycia szczecinianami.

Kolejnym aspektem zbiorowej autopercepcji szczecinian widzianej w kontekście zakorzenienia jest ich stosunek do stwierdzenia Gdy myślę ogólnie o mieszkańcach Szczecina,

\footnotetext{
${ }^{5}$ Wartość współczynnika skośności $\left(\mathrm{W}_{\mathrm{sk}}=-0,16\right)$ świadczy o tym, że mamy do czynienia z minimalną lewostronną asymetrią, czyli obserwujemy nieznacznie więcej przypadków powyżej niż poniżej wartości średniej arytmetycznej.

${ }^{6}$ Wartość współczynnika skośności $\left(\mathrm{W}_{\mathrm{sk}}=0,99\right)$ świadczy o tym, że mamy do czynienia z dużą prawostronną asymetrią, czyli obserwujemy znacznie więcej przypadków poniżej niż powyżej wartości średniej arytmetycznej.
} 
mogę o nich powiedzieć więcej dobrego niż złego. Pod względem ogólnego wyrazu rozkładów opinii na temat stwierdzenia zmienna geneza szczecińskiej tożsamości młodych mieszkańców nie odsłania jakichś szczególnych odmienności w sposobach postrzegania społeczeństwa Szczecina jako ogółu. Świadczy o tym najdobitniej niska - wyrażająca małą siłę związku - wartość współczynnika $\mathrm{C}_{\text {kor }}$-Pearsona. Wyraźna przewaga pozytywnych

\section{Wykres 9}

Rozkład opinii na temat stwierdzenia Gdy myślę o mieszkańcach Szczecina, mogę o nich powiedzieć więcej dobrego niż złego ze względu na genezę szczecińskiej tożsamości mieszkańców w wieku 25-44 lata i ze względu na szczecińskie korzenie rodzinne

Stwierdzenie 2: Gdy myślę o mieszkańcach Szczecina, mogę o nich powiedzieć więcej dobrego niż złego

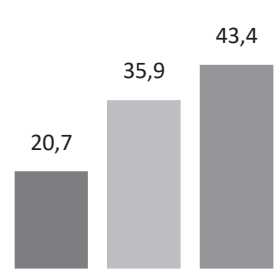

Urodzeni w Szczecinie

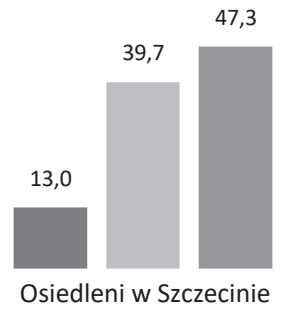

53,3

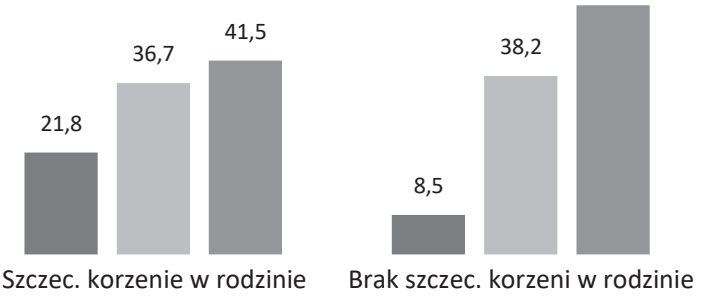

niezgadzający się z twierdzeniem $\quad$ Niezdecydowani $\quad$ Zgadzający się z twierdzeniem

Dane wyrażone w \%; $\mathrm{n}_{\text {urodzonych } w \text { Szczecinie }}=590=100 \%, \mathrm{n}_{\text {osiedlonych } w \text { Szczecinie }}=393=100 \%$;

$\mathrm{n}_{\text {mających szczecińskie korzenie } \mathrm{w} \text { rodzinie }}=670=100 \%, \mathrm{n}_{\text {niemających szczecińskich korzeni } \mathrm{w} \text { rodzinie }}=306=100 \%$.

Test Chi-kwadrat dla zależności między rozkładem opinii na temat stwierdzenia Gdy myślę o mieszkańcach Szczecina, mogę o nich powiedzieć więcej dobrego niż złego a genezą szczecińskiej tożsamości

$\begin{array}{lccc}\text { Statystyki } & \text { Wartości } & \text { df } & \text { Poziomy istotności } \\ \text { Chi-kwadrat Pearsona } & 9,65 & 2 & 0,01 \\ \text { Wskaźnik wiarygodności } & 9,96 & 2 & 0,01 \\ \text { Test trendu } & 5,80 & 1 & 0,02 \\ \text { Liczebność ważnych przypadków } & 983 & & \\ \text { Współczynnik siły związku C } \text { kor }_{\text {-Pearsona }} & 0,13 & & \end{array}$

Test Chi-kwadrat dla zależności między rozkładem opinii na temat stwierdzenia Gdy myślę o mieszkańcach Szczecina, mogę o nich powiedzieć więcej dobrego niż złego a zmienną szczecińskie korzenie w rodzinie

\section{Statystyki}

Chi-kwadrat Pearsona

Wskaźnik wiarygodności

Test trendu

Liczebność ważnych przypadków

Współczynnik siły związku $\mathrm{C}_{\text {kor }}$-Pearsona

Źródło: badania własne.

$\begin{array}{ccc}\text { Wartości } & \text { df } & \text { Poziomy istotności } \\ 27,64 & 2 & 0,00 \\ 30,45 & 2 & 0,00 \\ 23,89 & 1 & 0,00 \\ 976 & & \\ 0,22 & & \end{array}$


opinii nad negatywnymi, jak również niewiele różniący się w obydwu kategoriach omawianej zmiennej udział postaw niezdecydowania, a także udział opinii pozytywnych nie pozwalają traktować faktów urodzenia w Szczecinie oraz osiedlenia się w tym mieście jako znacząco różnicujących zbiorową percepcję. Można jednak odczytać z uzyskanych wyników - w ich bardziej szczegółowym oglądzie - dwa istotne konteksty warte uwagi i namysłu: po pierwsze, przekraczający 40\% (wśród urodzonych w Szczecinie), a nawet zbliżający się do 50\% (wśród tu osiedlonych) udział akceptacji przekonania o przewadze zalet szczecinian nad ich wadami daje asumpt do zorganizowanego działania odwołującego się do imponderabiliów pozostawiającej wiele do życzenia więzi lokalnej; po drugie, różnica

\section{Wykres 10}

Rozkład opinii na temat stwierdzenia Szczecinianom brakuje wzajemnej więzi ze względu na genezę szczecińskiej tożsamości mieszkańców w wieku 25-44 lata i ze względu na szczecińskie korzenie rodzinne

Stwierdzenie 3: Szczecinianom brakuje wzajemnej więzi

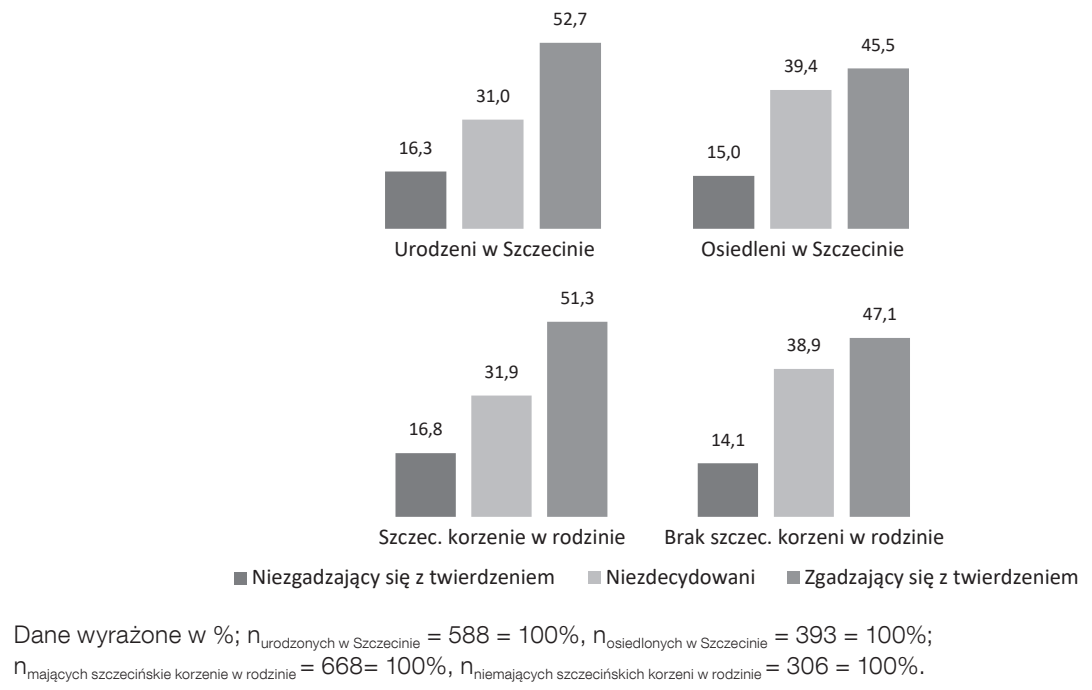

Test Chi-kwadrat dla zależności między rozkładem opinii na temat stwierdzenia Szczecinianom brakuje wzajemnej więzi a genezą szczecińskiej tożsamości

$\begin{array}{lccc}\text { Statystyki } & \text { Wartości } & \text { df } & \text { Poziomy istotności } \\ \text { Chi-kwadrat Pearsona } & 7,63 & 2 & 0,02 \\ \text { Wskaźnik wiarygodności } & 7,59 & 2 & 0,02 \\ \text { Test trendu } & 1,50 & 1 & 0,22 \\ \text { Liczebność ważnych przypadków } & 981 & & \\ \text { Współczynnik siły związku C } \text { kor }^{-} \text {Pearsona } & 0,13 & & \end{array}$

Test Chi-kwadrat dla zależności między rozkładem opinii na temat stwierdzenia Szczecinianom brakuje wzajemnej więzi a zmienną szczecińskie korzenie w rodzinie

\section{Statystyki}

Chi-kwadrat Pearsona

Wskaźnik wiarygodności

Test trendu

Liczebność ważnych przypadków

Źródło: badania własne.

Wartości
4,76
4,72
0,10
974

\section{Poziomy istotności}

0,09

0,09

0,76 
udziału opinii negatywnych, ujawniająca bardziej krytyczny stosunek rodowitych mieszkańców, zdaje się nieść istotny sygnał dotyczący możliwego zagrożenia dla pozytywnego efektu awansu społecznego wynikającego z osiedlenia się w dużym mieście mieszkańców małych miejscowości z głębi regionu. Głębsze i trwalsze - jak wynika z wcześniej przeprowadzonego wywodu - związki z miastem generują surowszy ogląd i charakterystykę mieszkańców Szczecina.

Stwierdzone prawidłowości jeszcze wyraźniej rysują się z perspektywy zmiennej szczecińskie korzenie rodzinne. Specyfika rozkładów wyrażająca się znacząco wyższym udziałem wśród osób niemających szczecińskich korzeni w rodzinach opinii świadczących o akceptacji treści analizowanego stwierdzenia oraz niemalże tak samo niższym udziałem opinii przeciwnych stanowi aż nadto jednoznaczny dowód sformułowanej powyżej tezy.

Mieszkańcy niewrośnięci pokoleniowo w społeczny organizm miasta, będący w większości przybyszami z całego Pomorza Zachodniego (jak również, w znaczącej części, z małych miejscowości w innych województwach), doświadczając awansu związanego z osiedleniem się w dużym mieście, asymilują się, czyli dążą do autoidentyfikacji jako szczecinianie w pełnym tego słowa znaczeniu. Wyraźnie rysująca się w ich przypadku tendencja do pozytywnego odbioru ogółu mieszkańców miasta znajduje w tym kontekście bodaj najprostsze uzasadnienie.

Otworzenie w analizie panoramy określonej przez zmienne zakorzenienia w celu interpretacji opinii na temat kolejnego stwierdzenia: Szczecinianom brakuje wzajemnej więzi, odsłania prawidłowości, które - wbrew odmienności w stosunku do poprzednio omówionego stwierdzenia pod względem udziałów opinii pozytywnych (tu brak zgody z treścią stwierdzenia) oraz opinii negatywnych (tu zgoda z treścią) - paradoksalnie wzmacniają dotychczasowe ustalenia. Osoby osiedlone w Szczecinie, a także te, które nie mają w mieście rodzinnych korzeni, „wrastając” w społeczny organizm miasta, cechują się - inaczej niż „wyrastający" z niego - zauważalną wstrzemięźliwością w formułowaniu opinii.

Jednoznaczny wydźwięk wysokiego udziału opinii potwierdzających przekonanie o ograniczonych więziach społecznych wśród mieszkańców Szczecina otwiera bardzo szerokie pole dla wypracowania nowych, przemyślanych przedstawień zbiorowych opierających się na głębokich konsultacjach społecznych w gronie ekspertów oraz zaangażowanych szczecinian, którym sprawa leży na sercu.

\section{LITERATURA}

Bauman, Z. (2006). Społeczeństwo w stanie oblężenia. Warszawa: Wydawnictwo Sic!

Białek, J., Dzierzgwa, R., Mackiewicz, M., Perzanowska-Przychodzka, E., Przybylska, L., Siłuszek, A., Sudak, S., Więckowska, E. (2011). Raport Polska 2011. Gospodarka - Społeczeństwo - Regiony. Warszawa: Ministerstwo Rozwoju Regionalnego.

Dulczewski, Z. (red.) (1971). Społeczeństwo Ziem Zachodnich. Studium porównawcze wyników badan socjologicznych w województwie zielonogórskim. Poznań: Wydawnictwo Instytutu Zachodniego.

Dulczewski, Z., Kwilecki, A. (red.) (1979). Pamiętniki osadników Ziem Odzyskanych. Poznań: Wydawnictwo Poznańskie.

Jałowiecki, B., Szczepański, M. (2002). Rozwój regionalny i lokalny w perspektywie socjologicznej. Tychy: Śląskie Wydawnictwo Naukowe WSZiNS. 
Kowalewski, M. (2011). „Tam gdzie był kiedyś Komitet Wojewódzki”. Czy istnieje wspólna pamięć o mieście? Studia Socjologiczne, 2-3 (60), 343-364.

Kowalewski, M. (2016). Protest miejski. Przestrzenie, tożsamości i praktyki niezadowolonych obywateli miast. Kraków: Zakład Wydawniczy Nomos.

Kubicki, P. (2016). Wynajdywanie miejskości. Polska kwestia miejska z perspektywy długiego trwania. Kraków: Zakład Wydawniczy Nomos.

Kwilecki, A. (1970). Ziemie Zachodnie w polskiej literaturze socjologicznej. Wybór tekstów. Poznań: Wydawnictwo Instytutu Zachodniego.

Nowak, S. (1985). Metodologia badań społecznych. Warszawa: Państwowe Wydawnictwo Naukowe.

Oppenheim, A.N. (2004). Kwestionariusze, wywiady, pomiary postaw. Poznań: Zysk i S-ka Wydawnictwo.

Terelak, A., Klepajczuk, B., Kołodziejczak, S. (2009). Poziom znajomości języków obcych wśród mieszkańców Szczecina i Koszalina oraz charakterystyka obcokrajowców studiujących w wyższych uczelniach obu miast. Raport z badania. Szczecin: Gmina Miasto Szczecin.

Terelak, A., Kołodziejczak, S. (2011). Poziom kompetencji językowych wśród mieszkańców Szczecina i Koszalina w zakresie wybranych języków obcych oraz charakterystyka obcokrajowców studiujących w wyższych uczelniach obu miast. Raport z badania. Szczecin: Gmina Miasto Szczecin.

Terelak, A., Kołodziejczak, S. (2012a). Praca za granicą w świadomości emigrantów zarobkowych z województwa zachodniopomorskiego. Szczecin: Wydawnictwo Zapol.

Terelak, A., Kołodziejczak, S. (2012b). Środowisko pracy w Polsce i za granicą w relacjach emigrantów zarobkowych z województwa zachodniopomorskiego. W: J. Leoński, L. Wątróbski (red.), Migracje Polaków - przeszłość i teraźniejszość. Zagadnienia teoretyczne oraz diaspora polska w Hiszpanii, Chorwacji, Francji, na Wegrzech, w Palestynie i Nowej Zelandii (s. 91-118). Szczecin: Ośrodek Studiów i Badań Polonijnych Uniwersytetu Szczecińskiego.

Terelak, A., Kołodziejczak, S. (2012c). Zagraniczne emigracje zarobkowe mieszkańców województwa zachodniopomorskiego a regionalny rynek pracy. Szczecin: Wydawnictwo Zapol.

Terelak, A., Kołodziejczak, S. (2013). Poziom kompetencji językowych - w zakresie języków obcych - wśród mieszkańców Szczecina mieszczących się w dynamicznych kategoriach wieku produkcyjnego oraz studentów szczecińskich uczelni wyższych stojących u progu wejścia na rynek pracy. Raport z badań. Szczecin: Gmina Miasto Szczecin.

Terelak, A., Kołodziejczak, S. (2016). Poziom kompetencji językowych - w zakresie języków obcych - wśród mieszkańców Szczecina mieszczących się w dynamicznych kategoriach wieku produkcyjnego oraz wśród stojących u progu wejścia na rynek pracy studentów szczecińskich uczelni. Raport z badań. Szczecin: Gmina Miasto Szczecin.

Terelak, A., Kołodziejczak, S. (w druku). Emigracje zarobkowe z Pomorza Zachodniego do Niemiec. W: Polen in Deutschland - Neue Formen, neue Welten und alte Traditionen. Chemnitz: Technische Universität Chemnitz.

Znaniecki, F. (1984). Miasto w świadomości jego obywateli. Z badań polskiego Instytutu Socjologicznego nad miastem Poznaniem. W: F. Znaniecki, J. Ziółkowski, Czym jest dla ciebie miasto Poznań? Dwa konkursy: 1928/1964 (s. 7-125). Warszawa-Poznań: Państwowe Wydawnictwo Naukowe.

Znaniecki, F. (1990). Współczesne narody. Warszawa: Państwowe Wydawnictwo Naukowe. 
SUMmARY The article presents the methodological assumptions and results of the research concerned with the perception of the capital of West Pomerania by its inhabitants. The research involved a survey conducted among the inhabitants of Szczecin within the mobile categories of working age (25-44). The findings address the issues of: 1) the general attitude towards Szczecin as a living space, which allows for determining to what degree the city is considered one's "own place in the world"; 2) the elements of collective self-perception of the inhabitants of Szczecin, expressed by grading a set of statements describing the city's society. The cognitively significant context of the analysis is established through a comparison of the perceptions of the city along with the variables of inveteracy (having been born in Szczecin or having settled in it; having family roots in Szczecin or the lack of such)

\section{KEYWORDS}

HUMAN CAPITAL, PERCEPTION OF THE CITY; SOCIAL IDENTITY, SOCIAL ROOTING IN, LOCAL TIES 